\title{
REAL-TIME STRUCTURAL HEALTH MONITORING FOR CONCRETE BEAMS: A COST-EFFECTIVE 'INDUSTRY 4.0' SOLUTION USING PIEZO SENSORS
}

\begin{tabular}{|r|l|}
\hline Journal: & International Journal of Building Pathology and Adaptation \\
\hline Manuscript ID & IJBPA-12-2019-0111.R3 \\
\hline Manuscript Type: & Original Article \\
\hline Keywords: & $\begin{array}{l}\text { Structural health monitoring, Industry 4.0, piezoceramic sensor, } \\
\text { concrete, Internet of things (IoT), Construction industry }\end{array}$ \\
\hline \multicolumn{2}{|l}{} \\
\hline
\end{tabular}

\section{SCHOLARONE \\ Manuscripts}


Ref: Manuscript ID IJBPA-12-2019-0111.R2

Journal: International Journal of Building Pathology and Adaptation

Title: Real-time structural health monitoring for concrete beams: a cost-effective 'industry 4.0' solution using piezo sensors

\section{REVIEWERS' COMMENTS AND AUTHORS' RESPONSE}

The authors wish to extend thanks to the referees once again for their constructive comments and suggestions. These minor comments have now been addressed and a final file resubmitted for your consideration using the 'tracked changes' feature within MS Word. Once again, thank you.

\begin{tabular}{|c|c|c|}
\hline No. & Reviewer & Authors' Response \\
\hline & \multicolumn{2}{|l|}{ Editor Comments } \\
\hline \multirow[t]{2}{*}{1} & $\begin{array}{l}\text { We are almost ready to accept your } \\
\text { manuscript for publication, however } \\
\text { there are a few minor points to be } \\
\text { addressed. }\end{array}$ & $\begin{array}{l}\text { Thank you - this has certainly been a } \\
\text { thorough process. }\end{array}$ \\
\hline & \multicolumn{2}{|l|}{ Referee No.1 } \\
\hline \multirow[t]{2}{*}{2} & $\begin{array}{l}\text { Accept - The authors have certainly } \\
\text { made significant effort in addressing } \\
\text { some of the reviewer's earlier comments, } \\
\text { and the quality of the manuscript has } \\
\text { significantly improved from the } \\
\text { 'originality' and 'contributions' } \\
\text { perspectives. }\end{array}$ & $\begin{array}{l}\text { Thank you for the constructive comments } \\
\text { and suggestions offered during the writing } \\
\text { and revision of this manuscript. Your } \\
\text { assistance is much appreciated. }\end{array}$ \\
\hline & \multicolumn{2}{|l|}{ Referee No.2 } \\
\hline 3 & $\begin{array}{l}\text { The authors have made effort to improve } \\
\text { the paper, further change would be made } \\
\text { to expand the research implication } \\
\text { section and make sure the originality are } \\
\text { aligned with the research aims and } \\
\text { objectives. }\end{array}$ & $\begin{array}{l}\text { The research implications section has been } \\
\text { expanded to include new text and an } \\
\text { additional citation viz: } \\
\text { "Hitherto, Industry } 4.0 \text { has received scant } \\
\text { academic attention within extant literature } \\
\text { but has already been successfully adopted } \\
\text { in more technologically advanced sectors } \\
\text { such as manufacturing (Al-Saeed et al., } \\
\text { 2020). The research presented therefore } \\
\text { provides a useful case study of Industry } 4.0 \\
\text { adoption and thus serves to generate wider } \\
\text { polemic debate and discussion within the } \\
\text { contemporary construction and civil } \\
\text { engineering management discipline." }\end{array}$ \\
\hline 4 & $\begin{array}{l}\text { The rationale of this research study is } \\
\text { interesting and meaning to the industry. } \\
\text { However, the solid explanations or } \\
\text { examples of its research implications are } \\
\text { neglect. The results and implications of } \\
\text { this research can be seen as practical. } \\
\text { More discussions on its implications on } \\
\text { theory and real work practices are looked }\end{array}$ & $\begin{array}{l}\text { Again, further new text has been added to } \\
\text { the practical implications section viz: } \\
\text { "For industry practitioners, the accurate } \\
\text { structural health monitoring of concrete } \\
\text { structures has been an historically } \\
\text { expensive and time consuming process. By } \\
\text { combining technologically advanced }\end{array}$ \\
\hline
\end{tabular}




\begin{tabular}{|l|l|}
\hline forward. & $\begin{array}{l}\text { industry } 4.0 \text { digital technologies with novel } \\
\text { low-cost sensors an automated hybrid } \\
\text { analysis system developed during this } \\
\text { research demonstrates enormous potential } \\
\text { to revolutionise the structural health } \\
\text { monitoring of concrete structures. More } \\
\text { specifically The developed system } \\
\text { redefines structural health monitoring of } \\
\text { concrete with some significant practical } \\
\text { implications implications viz:..." } \\
\text { And again at the and of this section viz: } \\
\text { "Cumulatively, the compelling evidence } \\
\text { reported upon in this paper should } \\
\text { stimulate wider academic research and } \\
\text { development and possibly expansion of the } \\
\text { advanced Industry } 4.0 \text { technologies } \\
\text { adopted to other areas of construction and } \\
\text { civil engineering management." }\end{array}$ \\
\hline
\end{tabular}




\title{
REAL-TIME STRUCTURAL HEALTH MONITORING FOR CONCRETE BEAMS: A COST-EFFECTIVE 'INDUSTRY 4.0’ \\ SOLUTION USING PIEZO SENSORS
}

\begin{abstract}
Purpose: This research paper adopts the fundamental tenets of advanced technologies in industry 4.0 to monitor the structural health of concrete beam members using cost effective non-destructive technologies. In so doing, the work illustrates how a coalescence of low-cost digital technologies can seamlessly integrate to solve practical construction problems.

Methodology: A mixed philosophies epistemological design is adopted to implement the empirical quantitative analysis of 'real-time' data collected via sensor-based technologies streamed through a Raspberry Pi and uploaded onto a cloud-based system. Data was analysed using a hybrid approach that combined both vibration characteristic based method and linear variable differential transducers (LVDT).

Findings: The research utilises a novel digital research approach for accurately detecting and recording the localisation of structural cracks in concrete beams. This nondestructive low-cost approach was shown to perform with a high degree of accuracy and precision, as verified by the LVDT measurements. This research is testament to the fact that as technological advancements progress at an exponential rate, the cost of implementation continues to reduce to produce higher accuracy 'mass-market' solutions for industry practitioners.

Originality: Accurate structural health monitoring of concrete structures necessitates expensive equipment, complex signal processing and skilled operator. The concrete industry is in dire need of a simple but reliable technique that can reduce the testing time, cost and complexity of maintenance of structures. This was the first experiment of its kind that seeks to develop an unconventional approach to solve the maintenance problem associated with concrete structures. This study merges industry 4.0 digital technologies with a novel low-cost and automated hybrid analysis for real-time structural health monitoring of concrete beams by fusing several multidisciplinary approaches in one integral technological configuration.
\end{abstract}

\section{KEYWORDS}


Structural health monitoring, Industry 4.0, piezoceramic sensor, Internet of Things (IoT), concrete, construction industry.

\section{INTRODUCTION}

Extant literature acknowledges the significance of implementing long-term structural health monitoring (SHM) (Sheikh et al., 2016) systems for civil infrastructures, in order to secure structural safety and issue incipient warnings of structural damage prior to costly repair ( $\mathrm{Li}$ et al., 2016). To underscore the scale of this operations and maintenance activity, the concrete repair industry in the US is estimated to generate 25 billion USD per year (Al-Mahaidi and Kalfat 2018). Indeed, over 25\% of Canadian concrete bridges are deemed to be structurally deficient (Cusson et al., 2011), and 85\% of high-rise buildings in New South Wales (NSW) built after 2000 had some form of structural failure (Randolph et al., 2019). SHM refers to a non-destructive process of implementing a damage identification and diagnosis strategy (Sohn et al., 2003). In the context of concrete members (cast in-situ or prefabricated), SHM refers to the detection of abnormalities or deformities (i.e., arising via deterioration, damage or failure) and provides information regarding structural health and integrity of concrete members for continued use (Agarwal et al., 2017; Zou et al., 2019).

The structural health of concrete members relies on several factors, including temperature (both external and internal), humidity, moisture content, applied stresses, and boundary conditions during manufacturing and its life cycle (Strangfeld et al., 2017; Tran et al., 2017). Structural members' design normally takes these factors into consideration (Ghodoosi et al., 2018). However, conditions are likely to change during the service life of concrete members, with the potential to significantly affect the overall health of the structure, providing the likelihood of deformations and failure (James et al., 2019). Moreover, designers can implement little control over the external conditions confronting concrete during its curing process (Joshi 2019; Moon et al., 2016).

In the current practice, several innovative and non-destructive methodologies have been developed to address the above challenges, including c-scan (Liu et al., 2019); x-rays (Marzec and Tejchman 2019); linear variable displacement transformers (LVDT) (Mohandoss et al., 2019); conventional microscopes (Jang et al., 2019). The aim is to identify and/or monitor structural deficiencies and cracks present in concrete structures 
especially aging infrastructure elements with an objective of provide early warning and redressal in the event of incipient partial or complete structural collapse. However, these techniques utilise large-sized (indeed, cumbersome) and expensive equipment that provide localised solutions, thus rendering them impractical and generally unattractive to industry practitioners (Sun et al., 2004; Yan et al., 2013). Moreover, existing techniques, for the most part, provide partial solutions to the monitoring requirements of the concrete industry. For example, LVDT sensors will provide insufficient information regarding the cause of the observed displacement (Subramanian and Murugesan 2019), and microscopes can only observe and measure localised surface deformations without any indication of below surface deformations (Bernard 2019).

The latest development in the field of SHM (Sheikh et al., 2016) came from sensors and sensor-based networks, data acquisition and communication, signal processing and data and information management ( $\mathrm{Li}$ et al., 2016). Researchers have also suggested the use of several forms of embedded and surface sensors in concrete to assess the concrete quality, economically (Taheri 2019b).

Piezoceramic, or piezoelectric sensors represent one viable option for monitoring the structural health of concrete structures by measuring the voltage generated by physical stress or strain on the sensor itself (Li et al., 2019). These sensors can either be embedded into a concrete member before casting or it can be attached to the external surface facilitating its use on both new and pre-existing structures (Xu et al., 2015). But the extent of its applicability has been hampered by the delay in signal processing development (Gao et al., 2016), the use of complicated signal analysis techniques like Fourier transform (Wang et al., 2019) and wavelet analysis (Jiang et al. 2017), which make the translation of its output, from research laboratories to industrial practice, difficult. These issues remain unresolved within extant literature. To address the above shortfalls, this research provides an innovative and low-cost industry 4.0 methodology for monitoring the structural health of concrete structural members. Associated objectives to be realised are to: 1) facilitate early detection and localisation of internal cracks in concrete members through real-time monitoring using Internet of Things (IoT) tools; 2) provide an economically viable tool for real-time data monitoring of concrete quality in a visually-engaging manner; 3) provide an affordable and accurate solution for industry practitioners; and 4) as a result of fulfilling the previous objectives, preserve the 
health, safety and welfare of building occupants.

\section{STRUCTURAL HEALTH MONITORING OF CONCRETE MEMBERS}

Various methods for SHM are applied across the industry to observe, record and analyse physical changes to structural members throughout their lifecycle (Lynch et al., 2016). Currently, conventional methods include different tests such as a simple human eye detection of surface defects (Ghodoosi et al., 2018) or a compressive strength test which only provides results after a 28 day curing period (Yildirim et al., 2015). The prevalence of such conventional testing methods in the construction industry has led to unpredictability and unreliability in assessing the structural health of concrete infrastructure (Asprone et al., 2018). Moreover, these methods are proven cumbersome with low efficacy and increasingly, are deemed impractical (Ghodoosi et al., 2018; Oesterreich and Teuteberg 2016). A list of major conventional methods on construction sites has been tabulated in Appendix 1, along with the limitations affecting each method as well as an associated costs comparison. As illustrated in Appendix 1, visual-based observation techniques such as the human eye, fibrescope, borescope, hand-held magnifier or stereo microscope are labour intensive and do not offer detailed or quantitative information about interior defects occurring internally within concrete members. Acoustic techniques such as the rebound hammer, ultrasonic pulse velocity (UPV), impact echo, spectral wave analysis, crosshole sonic lagging or parallel seismic have various limitations. These limitations include: the need for two-sided access to members; an inability to detect anomalies at a greater depth; limitations in resolution and imaging; complex signal processing; exorbitant costs of equipment; and the need for specialised training to operate acoustic equipment (Kaiser et al., 2004). These facts make such techniques unsuitable for practical use in concreting operations (Giri 2019). Set against this contextual backdrop, a paradigm shift has occurred in the market, where new low-cost and highly accurate digital methods are designed based on including sensors that can be embedded internally in new structures or on the surface of already existing structures (Li et al., 2016).

\section{Sensor-based methods}

The contemporary concreting industry has progressively moved away from cumbersome SHM tools and techniques (Zinno et al., 2019). Researchers are hence, actively looking for innovative Industry 4.0 solutions for monitoring of structures with the use of smart 
materials and sensors (Lehmhus et al., 2019) efficiently and economically; where Industry 4.0 represents a coalescence of digital and automated technologies working in unison (Edwards et al., 2017). In terms of utilisation of digital techniques for monitoring of concrete members, a series of research in digital SHM is redefining the way that structures are monitored and maintained (Concepcion et al., 2017). Appendix 2 presents various sensing techniques used in SHM of concrete members, their method, principle, application and limitations as well as associated costs for comparison purposes (Sheikh et al., 2016). As illustrated, most existing techniques are complex, expensive and operators require rigorous training to possess competency in these techniques. In the commercial market similar products are developed as: SmartRock2 (195 USD) for monitoring concrete strength; BlueRock (350 USD) for monitoring relative humidity to optimise curing; and SmartRock Plus to monitor temperature and strength of early age concrete in real-time and SmartBox (3500 USD) for monitoring electrical resistivity to provide useful information regarding water content and the setting and hardening time of concrete by Giatec Scientific, Canada (Giatec Scientific, 2020). Additionally AOMS, Canada provides similar concrete sensors, LumiCon (4000 USD) for monitoring temperature, strength, relative humidity, evaporation rate, maturity and temperature differential (AOMS Technology, 2020). However, until now there has not been a similar product for IoT-enabled structural health monitoring of concrete structures. This study proposes a novel technique with the help of a pilot study to address this research and provide industry with a viable accurate solution at an extremely affordable cost. Lowcost piezoceramic sensors (\$2.22 AUD each) and a raspberry pi model B 3+ (\$54 AUD) as a controller are identified as a viable alternative package for monitoring the structural health of concrete members.

\section{Piezoceramic Sensors}

Piezoceramic sensors have been utilised heavily for SHM in the aircraft industry (Chang 2016; Shen et al., 2006), automobile (Martinotto et al., 2016) and manufacturing (Hossain et al., 2016) industries. Various studies have also assessed the suitability of piezoceramic elements in assessing structural health of concrete members (Feng et al., 2018; Xu et al., 2018a; Zhao et al., 2016). The economical and easy applicability of piezoceramic sensors make them a viable option for SHM of concrete members in reallife projects (Shen et al., 2006). Piezoceramic elements are devices which create a voltage reaction when undergoing external stress due to vibration, soundwaves, or 
mechanical strain (Pan et al., 2019). Acting as a sensor, actuator, accelerator or transducer within the concrete member, the piezoceramic sensors detect the electrical energy converted from mechanical energy and convert it into a voltage output (Ballas and Schoen 2017). The mechanical energy developed from changes to the mechanical properties of a member (i.e. when a crack begins to form within the structure) is converted into electrical voltage fluctuations by the piezoceramic sensor (Xu et al., 2018b). As a crack grows in a concrete beam after loading, for example, the displacement from the original size and shape of the structure changes and then can be verified using an LVDT (Suárez et al., 2019).

There has been growing interest in using piezoceramic sensors in SHM for concrete members (Han et al., 2015; Song et al., 2007) even though Taheri (2019a) explored the advantages and disadvantages of varying SHM techniques with piezoceramic sensors. For example, water solubility and high humidity environments can affect the sensor (Mikulik and Linderman 2019). Moreover, Dong et al., (2019) suggest that the use of piezoceramic sensors may affect the mechanical properties of the concrete structure when they are embedded. In terms of installation, sensors embedded with no protection have corroded (Taheri 2019b). As cement continually reacts with water and develop strong bonds between mix components to build the final concrete strength, a protective layer is necessary to protect the embedded sensors from its boundary, moisture damage, and corrosion (Sanches et al., 2019). That said, these barriers can readily be overcome with cost-effective techniques. For example, Yan et al. (2013) discussed coating the piezoceramic patches in insulation as a method of preventing damage due to water or moisture. Yan et al. (2013), also embedded sensors into smaller sized concrete blocks to form a concrete smart aggregate and avoid physical damage that may occur to the delicate patches (where the latter may be damaged during curing of concrete members). In summary, although piezo elements have limitations of being fragile and non-water resistant, their economic feasibility and simplicity of usage provide strong arguments for using them on real-time SHM projects.

\section{RESEARCH PHILOSOPHY}

This overarching epistemological design for this research is to utilise a mixed methods philosophy to examine the phenomena under investigation (Al-Saeed et al. 2019) (e.g., the application of low-cost piezoceramic sensors to conduct real time SHM of concrete 
structures). Whilst interpretavism (Roberts et al. 2019) informs the research direction and methods of measurement employed (via qualitative analysis of literature), positivism is employed to conduct quantitative analysis of empirical data (Edwards et al. 2019). This combination of philosophies ensures that a scientifically robust research instrument is adopted.

\section{Research Approach}

When piezoceramic sensors are used to measure the mechanical properties of concrete, one of three common methods are often adopted: the impendence based method; the vibration characteristic based method; and the lamb-wave based method (Stojić et al., 2012). In this study, a hybrid method utilising the principles of the vibration characteristic based method is adopted to analyse the vibrational voltage feedback from surface-attached piezoelectric elements. This data is then correlated to strain displacements measurements collected by a LVDT electric strain gauge to assess crack detection and occurrence in four test sample members under various loading conditions. The hybrid approach is a novel combination of traditional LVDT testing and piezoceramic sensor vibrational voltage feedback to provide an accurate and early detection of cracks (Jeong-Beom and Fu-Kuo Chang 2004).

For data analysis, signal processing techniques were adopted including Fourier transform (ul Haq et al., 2017), Hilbert-Huang transform (Wei et al., 2016) and wavelet analysis (Jain et al., 2016). The wavelet method, an extension of the Fourier transform method, is commonly adopted within the field of electrical engineering as a valid and robust technique due to its developments in analysing non-stationary signals (Komorowski and Pietraszek 2016). However, Fourier transform, Hilbert-Huang transform and wavelet analysis methods require extensive mathematical computation and signal processing. Hence, for the purposes of this study, a simple hybrid analysis technique that correlates vibrational voltage feedback from piezoelectric elements and simple LVDT strain gauge displacements is adopted to facilitate easy adoption by industry practitioners.

\section{Concrete member design}

The design of the reinforced concrete beams follows a standard design procedure and complying with the Australian Standards AS3600-2009, for Reinforced Concrete 
Structures (see Standards Australia (2011) for details). The concrete test specimens are $150 \times 150 \times 500 \mathrm{~mm}$ in size and are reinforced with $4 \times 7.6 \mathrm{~mm}$ steel bars and five stirrups of the same diameter along the length of the beam. The beam will have $25 \mathrm{~mm}$ cover on all sides (refer to Figure 1). The mix-design and material composition of the M25 grade concrete members are provided in Table 1.

$<$ Insert Figure 1 and Table 1 about here $>$

\section{Decoding Raspberry Pi and electronic components used}

The main components used in the present 'Industry 4.0' study include: a Raspberry Pi; piezoceramic sensors; a breadboard; analogue to digital converter; and two 16-bit multiplexers (refer to Figure 2).

\section{$<$ Insert Figure 2 about here $>$}

- A Raspberry Pi is used as a computing unit to code the sensors and receive the data from these sensors. The Raspberry Pi microcontroller is a low cost, credit card-sized computer that plugs into a computer monitor or TV, and uses a standard keyboard and mouse, and uses much lesser power than other equivalent computing units (Raspberry Pi Foundation 2019).

- A piezoceramic sensor is a device that uses the piezoelectric effect to measure changes in pressure, acceleration, temperature, strain or force by converting them to an electrical charge. When a piezoceramic sensor is struck, it 'rings' like a bell but instead of sound it, it outputs a voltage spike that can be monitored in realtime.

- A breadboard comprises of a board in electronics that facilitates the prototyping of the circuit connecting the piezoceramic sensors to the Raspberry Pi.

- The analogue to digital converter (ADC), is utilised to convert the analogue data received from the piezoceramic sensor into digital signals that are passed to the Raspberry Pi.

- $\quad$ Two 16-bit multiplexers allow the simultaneous real-time data streaming from 13 piezo element sensors (with a maximum capacity of 2 X 16=32 piezo element sensors).

Screenshots of the data streaming on SmartWorks cloud platform is provided in Figure 3. The major electronic and IT activities of the experiment included (ref. Figure 2): 
- Hardware connections and developing circuits for connecting sensors to the Raspberry Pi;

- Coding the sensors and Raspberry Pi; and

- Attaching the sensors to the specimen and conducting the test.

$<$ Insert Figure 3 about here $>$

\section{EXPERIMENT AND ANALYSIS DESIGN}

The concrete mix components have been prepared, weighed, and dry mixed before adding the water using a lab scale mixer at Deakin's concrete laboratory. Then, the wet mix has been poured into the prepared moulds. Demoulding the hardened concrete samples conducted on the next day while all samples have been cured for 28 days in water baths so that the concrete can develop its full strength before testing. The piezoceramic sensors are then attached to the pre-determined locations on the surface of the beams (refer to Figures 4 and 6). One beam will be tested in flexure under threepoint loading set up. This beam will act as a benchmark to ensure that: 1) the sensors have been coded correctly; 2) there are enough sensors distributed throughout the beam; and 3) the sensors collect the relevant data.

Following the testing of the initial beam, essential changes on the test set up will be made to ensure correct test procedure is carried out for the remaining beams. As the data collected by the piezoceramic sensors is to be verified, LVDTs were set up for use throughout the flexural testing of each of the beams in locations relevant to those of the sensors. As the project concept highlights the use of microscopes for verification throughout the testing, DSLR (digital single-lens reflex) cameras will instead be used throughout testing to magnify points of interest along the beam as the loads are applied to show when surface deformations occur. Furthermore, surface cracks were visually monitored and measured to use as further reference material when comparing several results.

After the test, surface cracks of a smaller size (such as micro cracks $<10 \mu \mathrm{m}$ ) usually verified with the use of a microscope, and will be inspected visually via DSLR camera footage for the four beams. While testing the beams, three standard concrete cylinders, 
prepared from the same concrete mix of each beam and cured at the same condition, have been tested for compressive strength to verify the quality/grade of the concrete used for each beam.

$<$ Insert Figure 4 about here $>$

\section{Sensor Setup}

Sensors were attached to each beam externally using adhesive tape to ensure optimised surface contact between the sensors and the concrete beam. The four beams included 13 sensors for each beam with five on the front and rear faces of the beam, one on the base and two on the top (ref. Fig. 5 and 6). The final beam included five sensors where there were two on each of the front and rear faces and one on the base of the beam (refer to Figure 5).

\section{$<$ Insert Figure 5 about here $>$}

Setting up the sensors involved attaching the wiring by ensuring the male end of a wire was touching the exposed wire from the sensor and securing with tape. Each sensor initially had three wires attached to each of the protruding wires. Once the sensors are secured to the beam, the wires are connected to a breadboard which in turn is connected to the Raspberry Pi. Where the wire length previously connected to the sensors was not long enough, further extensions are attached ensuring that the length ends with a male connection point. Figures 5 and 6 illustrate the location of sensors attached to the beam while Figure 4 provides the overall test setup for conducting the experiments.

The incorporation of sensors in the setup, as shown in Figure 5, has been conducted carefully due to a number of reasons. First, it was anticipated that because the sensors will collect data within a range of $20-50 \mathrm{~mm}$, they were placed in the region of expected large damage on the beam. As the beam would be placed under three-point bending with the load applied at the span centre, the majority of sensors were positioned within this area where the applied maximum bending moment is located. The sensors positioned at the quarter lengths on beams one - three to allow for verifying data with the lasers positioned at these lengths on the soffit of the beam. 


\section{Three-point bending test}

The test is performed on the beams to achieve the ultimate flexural load. This is the maximum transverse load and the corresponding bending moment that the beam can tolerate before full structural failure. The testing frame is self-supported type and provide a full circle of loading system, while the loading has been introduced through a hydraulic jack with load cell to monitor the actual applied load. The testing frame has also LVDT attached to the system to monitor beam deflection during the test. All outputs have been connected to a control panel and data acquisitioning system to capture the load-displacement relationship of each test. During the testing, and due to the load action of the applied bending moment, excessive deformation, such as beam deflection and concrete cracking, are expected around the mid span region where the bending moment has peaked. Therefore, the piezoceramic sensors were attached towards the mid-section of the beam. The materials have the property of generating an electric charge when subjected to a mechanical strain (direct effect for sensor) and conversely, generate a mechanical strain when subjected to an applied electric field (Taheri 2019b). In the experiment, the piezoceramic sensors were proposed as the sensors used for monitoring the SHM of the concrete beams. The first three beams had thirteen piezoceramic sensors, attached to the beams soffit at a distance of $100 \mathrm{~mm}$. The fourth beam had five sensors attached to it. The size of a piezoceramic sensor is $2 \mathrm{~mm}$ in diameter. During the experiment, the test starts with load control at a rate of 0.016 $\mathrm{MPa} / \mathrm{second}$, while it has been changed to deflection control of $1 \mathrm{~mm} /$ minute at the later stages to ensure capturing the full load-deflection relationship and to avoid sudden failure and damages to the instrumentations. This allowed the beam to gradually undergo safe and observable crack detection without significant damage to the sensors. The ultimate load at which the structures failed was recorded as $88.37 \mathrm{kN}, 83.31 \mathrm{kN}$, $78.71 \mathrm{kN}$ and $89.61 \mathrm{kN}$ for test samples $1,2,3$ and 4 respectively. The time to final failure was recorded as $1170 \mathrm{~s}, 1036 \mathrm{~s}, 978 \mathrm{~s}$ and $1116 \mathrm{~s}$ respectively for each of the four samples.

\section{FROM EXPERIMENTS TO FINDINGS}

Final testing was carried on once the entire setup was ready. The beam was placed on the testing frame and ensuring that the marking were made in such a way that 13 sensors are connected to the correct location. A total of ten sensors on the face of sides of the beam were connected and two sensors were connected on the top surface and one sensor 
was connected on the bottom face of the beam (ref. Fig. 5 and 6). The load was gradually applied on the beams and the code was run at the start of loading and the loading on the beams continued till the specimen failed due to excessive deformation and concrete crushing. Data streams from the piezoceramic sensors were collected for all four samples in SmartWorks platform (refer to Figure 3) with technical support provided by AltAir Solutions Company (Agarwal and Alam 2018).

\section{Test Beam 1 (control test)}

Beam 1 had 13 sensors attached on the surfaces when the load was applied. Figure 7 shows that voltage of the piezoceramic sensors (namely sensor 1 to until sensor 13) with respect to time intervals where the cracks occurred. At initial time instant, the voltage fluctuation of the sensors is ignored. This is because the sensor fluctuations are due to the load being applied to the beam and not because any cracks were being formed. Figure 7 illustrates the strain displacement of Beam 1 measured using LVDT. The three major displacement spikes marked are the points of significant localised deformation (i.e. cracks) at loads equivalent to $24.7 \mathrm{kN}, 45.632 \mathrm{kN}$ and $50.664 \mathrm{kN}$ and stress equivalent to 4.94 $\mathrm{MPa}, 9.13 \mathrm{MPa}$ and 10.13MPa. When analysed clearly there was a huge voltage difference in sensors 1, 3, 4, 7 and sensor 13 where the cracks occurred. The piezoceramic sensor 2 was constant where there was no cracks formed and hence, there was no change in the voltage. The base voltage that the sensor generates in constant stage would be $0.60 \mathrm{~V}$. The increase in voltage is observed at locations where cracks are viewed through DSLR camera recordings. The time interval of the camera footage is matched with the recorded sensor readings and it is observed that voltage spikes match that of observed surface cracks at similar time instant. In fact the voltage spikes occur a few seconds before the surface cracks are observed on camera. Also certain micro-cracks and internal cracks which cannot be registered on camera or even on a microscope are easily detected through the piezoceramic sensors through minor voltage spikes. After a time interval of 1080 seconds, when the load applied was $88.37 \mathrm{kN}$ (as measured by the load cell), final structural failure occurred and all the sensors were observed producing high voltages at that particular time instant (ref Fig.6) which is evident in the graph. 
The analysis of graphs in Figures 7 proves that when there was a change in voltage in the sensors, there was an observable change in displacement at that particular time instant. Hence, the working sensors can detect even internal crack occurrence effectively. Also, the location of the sensors is helpful in determining the localisation of the occurred crack as shown in Figure 3. Similar tests are repeated for beams 2, 3, 4 respectively with similar displacement graphs obtained for the respective beams with the piezoceramic sensors detecting a spike in voltage at each of the major displacement spikes. Additionally, minor voltage spikes were observed which signify the occurrence of internal micro-cracks at that particular location. Hence, the piezoceramic sensors were successful in both real-time crack detection and localisation of cracks in concrete members.

\section{THEORETICAL AND MANAGERIAL IMPLICATIONS}

The multidisciplinary approach (using Industry 4.0 advanced technologies) adopted towards solving an important maintenance issues associated with the construction industry has some significant theoretical and managerial implications. Specifically, the work provides an economical and multi_featured addition to extant literature in the area of non-destructive testing (NDT) techniques (as outlined in Appendices 1 and 2). It also redefines the construction managerial landscape by ensuring remote maintenance assessment of concrete structures can be achieved without the need for on-site assessment. Such an approach could improve the cost efficiency of facilities management operations. Ferom a novel theroecticaltheoretical perspective, the work provides an insightful case study of tentative steps towards adopting an Industry 4.0 application in the concrete industry that could facilitate modernisation of this sector. Hitherto, Industry 4.0 has received scant academic attention within extant literature but has already been successfully adopted in more technologically advanced sectors such as manufacturing (Al-Saeed et al., 2020). The research presented therefore provides a useful case study of Industry 4.0 adoption and thus serves to generate wider polemic debate and discussion within the contemporary construction and civil engineering management discipline.

\section{PRACTICAL IMPLICATIONS}

For industry practitioners, the accurate structural health monitoring of concrete structures has been an historically expensive and time consuming process. By combining 
technologically advanced industry 4.0 digital technologies with novel low-cost sensors an automated hybrid analysis system developed during this research demonstrates enormous potential to revolutionise the structural health monitoring of concrete structures. More specifically, tThe developed system redefines structural health monitoring of concrete with some significant practical implictionsimplications viz:

- Retrospective quality control for concrete can be conducted seamlessly and in real-time but also shared remotely among all the stakeholders.

- Significant time savings (and by implication, cost savings) can be made in turnaround time required to obtain test results.

- Enhanced accuracy of test results and enhancement of the reliability of results achieved, trough removing subjective judgement and labour-based activities from the procedure.

- Improved interoperability of data generated when linked to new developments in the field like Building Information Modelling (BIM) and Digital Engineering (DE).

- Enhanced transferability of data across the supply chain to better inform practitioners involved in the post-construction stages and assist decision making on maintaining concrete structures.

- Facilitate lower construction costs and completion times, through omitting unnecessary and repeated operator controls in traditional monitoring and control systems.

- In long-term, improve durability and minimise the cost of repair and maintenance of concrete structure and reduce material waste that occurs due to the low quality of concrete.

- Ensure compliance with the relevant regulations and quality standards and in the long-term, improve the image and reputation of construction companies among the communities they serve.

Cumulatively, the compelling evidence reported upon in this paper should stimulate wider academic research and development and possibly expansion of the advanced Industry 4.0 technologies adopted to other areas of construction and civil engineering management. 


\section{CONCLUSIONS}

SHM of concrete is a significant research frontier that seeks to provide structural safety to both existing and future concrete structures providing an insurance against structural failure disasters. SHM plays a vital role due to the increase in the number of aging buildings or structures. While previous methods included traditional techniques to assess the structural integrity of concrete structures, current techniques have harnessed sensorbased techniques to provide real-time monitoring of concrete structures. However, many of these techniques suffer from the limitations of economic infeasibility or complex signal-processing techniques. This study investigates the application of low-cost piezoceramic sensors to detect deformations within the concrete structure (i.e., cracks and fractures) due to the member being placed under physical strain. Presently this method has been used on large scale infrastructure projects or some critical projects (Park et al., 2003; Su et al., 2018). The results of this study prove that piezoceramic sensors could detect both internal and external cracks and assist in real-time monitoring of concrete structures. This study also serves as a real-life application of Industry 4.0 in the construction sector and consequently, reveals how technology can automated this process moving forwards.

\section{Future Work Recommendations}

The demonstrated method is suitable for an autonomous continuous monitoring system because the data acquisition procedure can be computerised and requires minimal user interference. However, this approach being a preliminary scoping study had several limitations and some significant lessons for future studies. The use of wired sensors and its complex and sensitive circuit could potentially lead to delays and damage to devices. Hence, adequate protection of sensors and the development of wireless sensors is crucial for translating research into heavy duty industry applications. Adequate sensor concrete adhesion must be ensured to ensure reliability of collected readings - longitudinal research is therefore needed to assess the longevity and robustness of possible glues and/or resins that could be used. Studies investigating the exact range and lifespan of piezoceramic sensors could also further assist in fine-tuning this technique for industrial use. An analysis regarding suitable density of sensors by optimising the code used in the high stress region to capture the strain mapping could lead to more accurate indication of the critical regions of the structural element. 


\section{ACKNOWLEDGEMENTS}

The authors would like to extend their gratitude to Deakin University concrete laboratory, especially to Mr. Ikramul Mohammad, lab technical advisor and undergraduate student Ms. Emmy Glassen from School of Civil Engineering, Deakin University and Mr. Avinash Putta and Ms. Aishwarya Sanjay from School of Architecture and Built Environment for their assistance in performing the experiments as well as to the AltAir, Melbourne team especially Mr. Venkata Perumal for assisting with calibration and integration of sensors in an IoT platform. 


\section{REFERENCE}

Abouali, S, Shahverdi, M, Ghassemieh, M \& Motavalli, M 2019, 'Nonlinear simulation of reinforced concrete beams retrofitted by near-surface mounted iron-based shape memory alloys', Engineering structures, vol. 187, pp. 133-48.

Agarwal, P \& Alam, M 2018, 'Investigating IoT Middleware Platforms for Smart Application Development', arXiv preprint arXiv:1810.12292.

Agarwal, V, Neal, KD, Mahadevan, S \& Adams, D 2017, Concrete Structural Health Monitoring in Nuclear Power Plants, Idaho National Lab.(INL), Idaho Falls, ID (United States).

Al-Mahaidi, R \& Kalfat, R 2018, Rehabilitation of Concrete Structures with Fiber-reinforced Polymer, Butterworth-Heinemann.

Al-Saeed, Y, Parn, E, Edwards, DJ \& Scaysbrook, S 2019, 'A conceptual framework for utilising BIM digital objects (BDO) in manufacturing design and production: A case study', Journal of Engineering, Design and Technology. Vol. 17 No. 5, pp. 960-984.

Al-Saeed, Y., Edwards, D. and Scaysbrook, S. (2020) Automating construction manufacturing procedures using BIM digital objects (BDOs): Case study of knowledge transfer partnership project in UK, Construction Innovation, Vol. ahead-of-print No. ahead-ofprint. DOI: https://doi.org/10.1108/CI-12-2019-0141

Alani, AM, Aboutalebi, M \& Kilic, G 2014, 'Integrated health assessment strategy using NDT for reinforced concrete bridges', Ndt E International, vol. 61, pp. 80-94.

Anton, O, Komárková, T \& Heřmánková, V 2019, 'An optimal method of determining the position of bends on shear reinforcement as part of the diagnosis of reinforced concrete beam structures', in IOP Conference Series: Materials Science and Engineering, vol. 549, p. 012015 .

AOMS Technology. (2020, January 23). AOMS LumiCon. Retrieved from AOMS : https://www.aoms-tech.com/concrete-monitoring/

Asprone, D, Menna, C, Bos, FP, Salet, TA, Mata-Falcón, J \& Kaufmann, W 2018, 'Rethinking reinforcement for digital fabrication with concrete', Cement and Concrete Research, vol. 112, pp. 111-21.

Baeza, F, Galao, O, Zornoza, E \& Garcés, P 2013, 'Multifunctional cement composites strain and damage sensors applied on reinforced concrete (RC) structural elements', Materials, vol. 6 , no. 3, pp. 841-55.

Ballas, RG \& Schoen, D 2017, 'A non-contact inductive sensor for high-accuracy tip deflection measurements of piezoceramic bending actuators', in 2017 International Conference on Research and Education in Mechatronics (REM), pp. 1-6.

Barnes, CL, Trottier, J-F \& Forgeron, D 2008, 'Improved concrete bridge deck evaluation using GPR by accounting for signal depth-amplitude effects', NDT E International, vol. 41, no. 6, pp. 427-33.

Bernard, ES 2019, 'Predicting crack widths in FRC/reinforced concrete members using small deformation post-crack parameters', Structural Concrete.

Bień, J, Kamiński, T \& Kużawa, MJAoC 2019, 'Taxonomy of non-destructive field tests of bridge materials and structures', Archives of CivilMechanical Engineering, vol. 19, no. 4, pp. 1353-67.

Camacho-Ballesta, C, Galao, Ó, Baeza, FJ, Zornoza, E \& Garcés, P 2019, 'Durability and Mechanical Properties of CNT Cement Composites', in Service Life and Durability of Reinforced Concrete Structures, Springer, pp. 31-41.

Chang, C-Y \& Hung, S-S 2012, 'Implementing RFIC and sensor technology to measure temperature and humidity inside concrete structures', Construction Building Materials, vol. 26, no. 1, pp. 628-37.

Chang, F-K 2016, Self Diagnostic Adhesive for Bonded Joints in Aircraft Structures, Leland Stanford Junior Univ CA Stanford United States.

Cikrle, P, Hüblová, S, Kocáb, D \& Karel, O 2019, 'Non-destructive diagnostics of steelreinforced concrete structures: detecting and locating reinforcement', in IOP Conference Series: Materials Science and Engineering, vol. 549, p. 012010.

Concepcion, RS, Cruz, FRG, Uy, FAA, Baltazar, JME, Carpio, JN \& Tolentino, KG 2017, 
'Triaxial MEMS digital accelerometer and temperature sensor calibration techniques for structural health monitoring of reinforced concrete bridge laboratory test platform', in 2017IEEE 9th International Conference on Humanoid, Nanotechnology, Information Technology, Communication and Control, Environment and Management (HNICEM), pp. $1-6$.

Cusson, D, Lounis, Z \& Daigle, L 2011, 'Durability monitoring for improved service life predictions of concrete bridge decks in corrosive environments', Computer-Aided Civil and Infrastructure Engineering, vol. 26, no. 7, pp. 524-41.

Davis, A, Ansari, F, Gaynor, R, Lozen, K, Rowe, T, Caratin, H, Heidbrink, F, Malhotra, V, Simons, B \& Carino, N 1998, 'Nondestructive test methods for evaluation of concrete in structures', American Concrete Institute, ACI, vol. 228.

Dong, W, Li, W, Tao, Z \& Wang, K 2019, 'Piezoresistive properties of cement-based sensors: review and perspective', Construction and Building Materials, vol. 203, pp. 146-63.

Edwards, D, Pärn, EA, Sing, MC \& Thwala, WD 2019, 'Risk of excavators overturning: Determining horizontal centrifugal force when slewing freely suspended loads', Engineering, Construction and Architectural Management, vol. 26, no. 3, pp. 479-98.

Edwards, DJ, Pärn, E, Love, PE \& El-Gohary, H 2017, 'Research note: Machinery, manumission, and economic machinations', Journal of Business Research, vol. 70, pp. 391-4.

Fan, X, Shang, S, Song, D, Sun, W \& Li, D 2011, 'Cross-Range Super-Resolution Algorithm Based on Non-synthetic Aperture Radar', in 2011 Fourth International Symposium on Knowledge Acquisition and Modeling, pp. 88-91.

Feng, Q, Cui, J, Wang, Q, Fan, S \& Kong, Q 2018, 'A feasibility study on real-time evaluation of concrete surface crack repairing using embedded piezoceramic transducers', Measurement, vol. 122, pp. 591-6.

Gao, S, Dai, X, Liu, Z \& Tian, G 2016, 'High-performance wireless piezoelectric sensor network for distributed structural health monitoring', International Journal of Distributed Sensor Networks, vol. 2016, p. 27.

Garcia, S \& Deby, F 2019, 'Numerical and Experimental Development of Gradient Potential Measurement for Corrosion Detection in Reinforced Concrete', Service Life Durability of Reinforced Concrete Structures, p. 71.

Ghodoosi, F, Bagchi, A, Zayed, T \& Hosseini, MR 2018, 'Method for developing and updating deterioration models for concrete bridge decks using GPR data', Automation in Construction, vol. 91, pp. 133-41.

Giri, P 2019, 'Integrated approaches for non-destructive testing of construction materials and structures'.

Giatec Scientific. (2020, January 23). Giatec SmartRock. Retrieved from Giatec Scientific: https://www.giatecscientific.com/products/concrete-sensors/smartrock-maturity-meter/

Gokhan, K 2013, 'Application of advanced non-destructive testing methods on bridge health assessment and analysis [PhD thesis]', Doctorate in Philosophy thesis, University of Greenwich.

Han, B, Wang, Y, Dong, S, Zhang, L, Ding, S, Yu, X \& Ou, J 2015, 'Smart concretes and structures: A review', Journal of intelligent material systems structures, vol. 26, no. 11, pp. 1303-45.

Hossain, MS, Gonzalez, JA, Hernandez, RM, Shuvo, MAI, Mireles, J, Choudhuri, A, Lin, Y \& Wicker, RB 2016, 'Fabrication of smart parts using powder bed fusion additive manufacturing technology', Additive Manufacturing, vol. 10, pp. 58-66.

Howser, R, Dhonde, H \& Mo, Y 2011, 'Self-sensing of carbon nanofiber concrete columns subjected to reversed cyclic loading', Smart materials and structures, vol. 20, no. 8, p. 085031.

Ihn, Jeong-Beom, and Fu-Kuo Chang. "Detection and monitoring of hidden fatigue crack growth using a built-in piezoelectric sensor/actuator network: I. Diagnostics." Smart materials and structures 13.3 (2004): 609.

Jain, S, Prakash, SS \& Subramaniam, K 2016, 'Monitoring of concrete cylinders with and without steel fibers under compression using piezo-ceramic smart aggregates', Journal of 
Nondestructive Evaluation, vol. 35, no. 4, p. 59.

James, A, Bazarchi, E, Chiniforush, AA, Aghdam, PP, Hosseini, MR, Akbarnezhad, A, Martek, I \& Ghodoosi, F 2019, 'Rebar corrosion detection, protection, and rehabilitation of reinforced concrete structures in coastal environments: A review', Construction and Building Materials, vol. 224, pp. 1026-39.

Jang, Y, Ahn, Y \& Kim, HY 2019, 'Estimating compressive strength of concrete using deep convolutional neural networks with digital microscope images', Journal of Computing in Civil Engineering, vol. 33, no. 3, p. 04019018.

Jiang, T, Kong, Q, Patil, D, Luo, Z, Huo, L \& Song, G 2017, 'Detection of debonding between fiber reinforced polymer bar and concrete structure using piezoceramic transducers and wavelet packet analysis', IEEE Sensors Journal, vol. 17, no. 7, pp. 1992-8.

Joshi, SJIH 2019, 'Cement Concrete Curing: Its significance \& assurance at Project Site', vol. 47, no. 4.

Kachanov, V, Sokolov, I, Kontsov, R, Lebedev, S \& Fedorenko, S 2019, 'Ultrasonic wave velocity measurement in concrete using the impact-echo method', Insight-Non-Destructive Testing Condition Monitoring, vol. 61, no. 1, pp. 15-9.

Kaiser, H, Karbhari, V \& Sikorsky, C 2004, 'Non-destructive testing techniques for FRP rehabilitated concrete. II: an assessment', International Journal of Materials and Product Technology, vol. 21, no. 5, pp. 385-401.

Kaklauskas, G, Sokolov, A, Ramanauskas, R \& Jakubovskis, R 2019a, 'Reinforcement strains in reinforced concrete tensile members recorded by strain gauges and FBG sensors: experimental and numerical analysis', Sensors, vol. 19, no. 1, p. 200.

Kaklauskas, G, Sokolov, A, Ramanauskas, R \& Jakubovskis, R 2019b, 'Reinforcement strains in reinforced concrete tensile members recorded by strain gauges and FBG sensors: experimental and numerical analysis', Sensors, vol. 19, no. 1, p. 200.

Karthick, S, Muralidharan, S, Lee, H-S, Kwon, S-J \& Saraswathy, V 2019, 'Reliability and longterm evaluation of GO-MnO2 nano material as a newer corrosion monitoring sensor for reinforced concrete structures', Cement and Concrete Composites, vol. 100, pp. 74-84.

Khajehnouri, Y, Chouteau, M, Rivard, P \& Bérubé, CL 2019, 'Measuring electrical properties of mortar and concrete samples using the spectral induced polarization method: laboratory set-up', Construction and Building Materials, vol. 210, pp. 1-12.

Komorowski, D \& Pietraszek, S 2016, 'The use of continuous wavelet transform based on the fast fourier transform in the analysis of multi-channel electrogastrography recordings', Journal of medical systems, vol. 40, no. 1, p. 10.

Lehmhus, D, von Hehl, A, Hausmann, J, Kayvantash, K, Alderliesten, R \& Hohe, JJAEM 2019, 'New Materials and Processes for Transport Applications: Going Hybrid and Beyond'.

Li, H-N, Ren, L, Jia, Z-G, Yi, T-H \& Li, D-S 2016, 'State-of-the-art in structural health monitoring of large and complex civil infrastructures', Journal of Civil Structural Health Monitoring, vol. 6, no. 1, pp. 3-16.

Li, X, Luo, M, Hei, C \& Song, G 2019, 'Quantitative Evaluation of Debond in Concrete-filled Steel Tubular Member (CFSTM) Using Piezoceramic Transducers and Ultrasonic Head Wave Amplitude', Smart Materials Structures.

Liu, H, Xia, H, Zhuang, M, Long, Z, Liu, C, Cui, J, Xu, B, Hu, Q \& Liu, QH 2019, 'Reverse time migration of acoustic waves for imaging based defects detection for concrete and CFST structures', Mechanical Systems and Signal Processing, vol. 117, pp. 210-20.

Lynch, JP, Farrar, CR \& Michaels, JE 2016, 'Structural health monitoring: technological advances to practical implementations [scanning the issue]', Proceedings of the IEEE, vol. 104 , no. 8, pp. 1508-12.

Martinotto, L, Merlo, F \& Donzelli, D 2016, Method for manufacturing a braking element with integrated sensor, in particular a brake pad, brake pad with integrated sensor, vehicle braking system and associated method, Google Patents.

Marzec, I \& Tejchman, J 2019, 'Fracture evolution in concrete compressive fatigue experiments based on X-ray micro-CT images', International Journal of Fatigue, vol. 122, pp. $256-72$.

Mehdinia, S, Schumacher, T, Wan, E \& Song, X 2019, 'Diagnostic Imaging of Structural Concrete Using Ground Penetrating Radar and Ultrasonic Array'.

Mikulik, D \& Linderman, L 2019, 'Environmental Effects on Conductive Surface Sensors and 
Pattern Applications for Concrete Crack Localization', Journal of Materials in Civil Engineering, vol. 31, no. 6, p. 04019084.

Mohandoss, P, Kompella, SK \& Pillai, RG 2019, 'Bond Performance of Pretensioned Concrete Systems', in Recent Advances in Structural Engineering, Volume 1, Springer, pp. 277-86.

Moon, S, Zekavat, PR \& Bernold, LE 2016, 'Dynamic quality control of process resource to improve concrete supply chain', Journal of Construction Engineering Management, vol. 143 , no. 5, p. 04016130.

Moyo, P, Brownjohn, J, Suresh, R \& Tjin, S 2005, 'Development of fiber Bragg grating sensors for monitoring civil infrastructure', Engineering structures, vol. 27, no. 12, pp. 1828-34.

Niederleithinger, E, Maak, S, Mielentz, F, Effner, UA, Strangfeld, C \& Timofeev, J 2019, 'Review of recent developments in ultrasonic echo testing of concrete'.

Oesterreich, TD \& Teuteberg, F 2016, 'Understanding the implications of digitisation and automation in the context of Industry 4.0: A triangulation approach and elements of a research agenda for the construction industry', Computers in industry, vol. 83, pp. 121-39.

Pan, HH, Wong, Y-D \& Su, Y-M 2019, 'Piezoelectric cement sensor and impedance analysis for concrete health monitoring', in Nondestructive Characterization and Monitoring of Advanced Materials, Aerospace, Civil Infrastructure, and Transportation XIII, vol. 10971, p. 109710Y.

Paquet, J 1991, 'A new method for testing integrity of piles by dynamic impulse: the impedance log', in International Colloquium on Deep Foundations, Paris, March, pp. 1-10.

Park, G, Sohn, H, Farrar, CR \& Inman, DJ 2003, 'Overview of piezoelectric impedance-based health monitoring and path forward', Shock and Vibration Digest, vol. 35, no. 6, pp. 45164.

Park, S, Stubbs, N, Bolton, R, Choi, S \& Sikorsky, C 2001, 'Field Verification of the Damage Index Method in a Concrete Box-Girder Bridge via Visual Inspection', Computer-Aided Civil Infrastructure Engineering, vol. 16, no. 1, pp. 58-70.

Patrick, H, Williams, G, Kersey, A, Pedrazzani, J \& Vengsarkar, A 1996, 'Hybrid fiber Bragg grating/long period fiber grating sensor for strain/temperature discrimination', IEEE Photonics Technology Letters, vol. 8, no. 9, pp. 1223-5.

Randolph, B, Crommelin, L, Easthope, H \& Troy, L 2019, Submission to NSW Parliamentary Inquiry re: Regulation of building standards, building quality and building disputes, City Futures Research Centre, UNSW Sydney, Sydney.

Rashidyan, S, Maji, A \& Ng, T-t 2019, 'Performance of Nondestructive Parallel Seismic Testing Method in Determining Depth of Shallow Foundations', Journal of Performance of Constructed Facilities, vol. 33, no. 2, p. 06019001.

Raspberry Pi Foundation 2019, Raspberry Pi 3 Model B+, Raspberry Pi Foundation, retrieved 24 October 2019, <https://www.raspberrypi.org/products/raspberry-pi-3-model-b-plus/ $>$.

Roberts, C, Edwards, DJ, Hosseini, MR, Mateo-Garcia, M \& Owusu-Manu, D-G 2019, 'Postoccupancy evaluation: a review of literature', Engineering, Construction and Architectural Management. Vol. 26 No. 9, pp. 2084-2106.

Rocha, JHA, Póvoas, YV \& Santos, CFE 2019, 'Detection of Delaminations in SunlightUnexposed Concrete Elements of Bridges Using Infrared Thermography', Journal of Nondestructive Evaluation, vol. 38, no. 1, p. 8.

Rodriguez-Roblero, M, Ayon, J, Cascante, G, Pandey, M, Alyousef, R \& Topper, T 2019, 'Application of correlation analysis techniques to surface wave testing for the evaluation of reinforced concrete structural elements', NDT E International, vol. 102, pp. 68-76.

Sanches, A, Teixeira, G, Zaghete, M, Longo, E, Malmonge, J, Silva, M \& Sakamoto, W 2019, 'Influence of polymer insertion on the dielectric, piezoelectric and acoustic properties of 1-0-3 polyurethane/cement-based piezo composite', Materials Research Bulletin, vol. 119, p. 110541 .

Sheikh, A, Lakshmipath, M \& Prakash, A 2016, 'Application of queuing theory for effective equipment utilization and maximization of productivity in construction management', International Journal of Applied Engineering Research, vol. 11, no. 8, pp. 5664-72.

Sheikh, A, Lakshmipathy, M \& Prakash, A 2016, 'Application of queuing theory for effective equipment utilization and maximization of productivity in construction management', International Journal of Applied Engineering Research, vol. 11, no. 8, pp. 5664-72. 
Shen, B, Yang, X \& Li, Z 2006, 'A cement-based piezoelectric sensor for civil engineering structure', Materials and structures, vol. 39, no. 1, pp. 37-42.

Sohn, H, Farrar, CR, Hemez, FM, Shunk, DD, Stinemates, DW, Nadler, BR \& Czarnecki, JJ 2003, 'A review of structural health monitoring literature: 1996-2001', Los Alamos National Laboratory, USA.

Song, G, Gu, H, Mo, Y, Hsu, T \& Dhonde, H 2007, 'Concrete structural health monitoring using embedded piezoceramic transducers', Smart Materials and Structures, vol. 16, no. 4, p. 959.

Standards Australia 2011, Reinforced Concrete Design : in accordance with AS 3600-2009, Cement \& Concrete Aggregates Australia and Standards Australia, retrieved 24 October 2019, <https://nla.gov.au/nla.cat-vn5779703>.

Stojić, D, Nestorović, T \& Marković, N 2012, 'The application of piezoelectric transducers in the structural health monitoring of reinforce concrete structures', International Multidisciplinary Scientific GeoConference: SGEM:Surveying Geology mining Ecology Management, vol. 2, p. 641.

Strangfeld, C, Johann, S, Müller, M \& Bartholmai, M 2017, 'Embedded passive RFID-based sensors for moisture monitoring in concrete', in 2017 IEEE SENSORS, pp. 1-3.

Su, H, Zhang, N \& Li, H 2018, 'Concrete piezoceramic smart module pairs-based damage diagnosis of hydraulic structure', Composite Structures, vol. 183, pp. 582-93.

Suárez, F, Gálvez, J, Enfedaque, A \& Alberti, M 2019, 'Modelling fracture on polyolefin fibre reinforced concrete specimens subjected to mixed-mode loading', Engineering Fracture Mechanics, vol. 211, pp. 244-53.

Subramanian, R \& Murugesan, A 2019, 'Horizontal Thrust in Vertically Curved Reinforced Concrete Beams', Practice Periodical on Structural Design Construction, vol. 24, no. 2, p. 04019005.

Sun, M, Staszewski, W, Swamy, R \& Li, Z 2004, 'Surface wave method in piezoceramic patches/concrete smart structure', Journal of Building Materials, vol. 7, no. 2, pp. 145-9.

Taheri, S 2019a, 'A review on five key sensors for monitoring of concrete structures', Construction and Building Materials, vol. 204, pp. 492-509.

Taheri, S 2019b, 'A review on five key sensors for monitoring of concrete structures', Construction Building Materials, vol. 204, pp. 492-509.

Tran, QH, Han, D, Kang, C, Haldar, A \& Huh, J 2017, 'Effects of ambient temperature and relative humidity on subsurface defect detection in concrete structures by active thermal imaging', Sensors, vol. 17, no. 8, p. 1718.

ul Haq, M, Bhalla, S \& Naqvi, T 2017, 'Fatigue damage assessment of RC column using PZT sensors', Procedia engineering, vol. 173, pp. 1223-30.

Venkatraman, B \& Raj, B 2019, 'An Overview of Techniques and Application for Quality Evaluation', Non-Destructive Evaluation of Corrosion Corrosion-assisted Cracking, vol. 1980, p. 1.

Wang, Y, Li, X, Li, J, Wang, Q, Xu, B \& Deng, J 2019, 'Debonding damage detection of the CFRP-concrete interface based on piezoelectric ceramics by the wave-based method', Construction and Building Materials, vol. 210, pp. 514-24.

Wei, S, Shi, Y, Li, J \& Gangbing, S 2016, 'Monitoring Technology for Crack Damage of Concrete Structure Based on Piezoelectric Wave Method [J]', Engineering Mechanics, vol. 30, pp. 206-11.

White, B, Nagy, M \& Allin, R 2008, 'Comparing cross-hole sonic logging and low-strain integrity testing results', in Proceedings of the Eighth International Conference on the Application of Stress Wave Theory to Piles, pp. 471-6.

Wu, S, Dai, H \& Wang, W 2007, 'Effect of CFRC layers on the electrical properties and failure mode of RC beams strengthened with CFRC composites', Smart materials and structures, vol. 16, no. 6, p. 2056.

Xu, D, Banerjee, S, Wang, Y, Huang, S \& Cheng, X 2015, 'Temperature and loading effects of embedded smart piezoelectric sensor for health monitoring of concrete structures', Construction and Building Materials, vol. 76, pp. 187-93.

$\mathrm{Xu}, \mathrm{K}$, Deng, Q, Cai, L, Ho, S \& Song, G 2018a, 'Damage detection of a concrete column subject to blast loads using embedded piezoceramic transducers', IEEE Sensors Journal, 
vol. 18, no. 5, p. 1377.

Xu, K, Ren, C, Deng, Q, Jin, Q \& Chen, X 2018b, 'Real-time monitoring of bond slip between GFRP bar and concrete structure using piezoceramic transducer-enabled active sensing', Sensors, vol. 18, no. 8, p. 2653.

Yan, S, Wu, J, Sun, W, Ma, H \& Yan, H 2013, 'Development and application of structural health monitoring system based on piezoelectric sensors', International Journal of Distributed Sensor Networks, vol. 9, no. 11, p. 270927.

Yang, K, Wang, Y, Long, A, Yang, C, Mu, S \& Basheer, M 2019, 'Design of a steady-state in situ test to determine the air permeability coefficient of covercrete', Construction and Building Materials, vol. 195, pp. 671-81.

Yildirim, ST, Meyer, C \& Herfellner, S 2015, 'Effects of internal curing on the strength, drying shrinkage and freeze-thaw resistance of concrete containing recycled concrete aggregates', Construction and Building Materials, vol. 91, pp. 288-96.

Zhang, D, Luo, Z, Liu, Z \& Wu, S 2004, 'Sensitivity of reinforced components of CFRC', $J$. Harbin Inst. Technol, vol. 36, no. 10, pp. 1411-3.

Zhao, J, Bao, T, Chen, S \& Kundu, T 2016, 'Smart aggregate-piezoceramic patch combination for health monitoring of concrete structures', Journal of Sensors, vol. 2016.

Zinno, R, Artese, S, Clausi, G, Magarò, F, Meduri, S, Miceli, A \& Venneri, A 2019, 'Structural Health Monitoring (SHM)', in The Internet of Things for Smart Urban Ecosystems, Springer, pp. 225-49.

Zou, D, Du, C, Liu, T \& Li, WJSM 2019, 'Effects of temperature on the performance of the piezoelectric-based smart aggregates active monitoring method for concrete structures', Smart materials and structures. 
Figure 1 - Reinforced concrete beam design
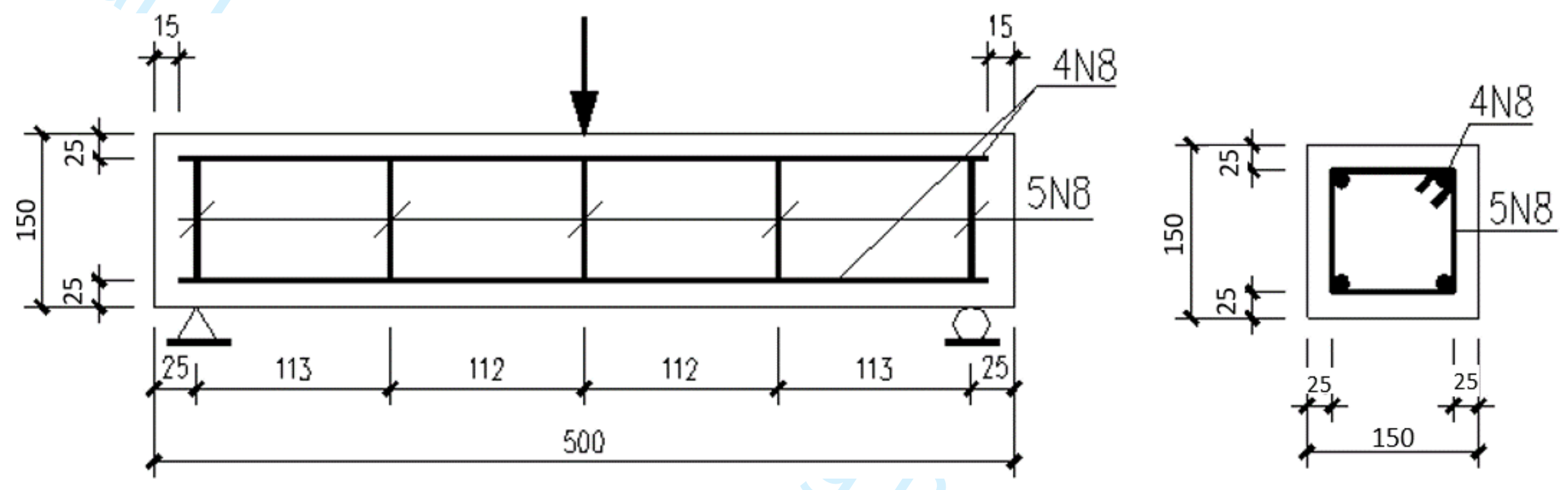
Table 1 - Concrete Mix design, material quantities

\begin{tabular}{lll}
\hline Material & Ratio & $\begin{array}{l}\text { Total Weight } \\
(\mathrm{kg})\end{array}$ \\
\hline Cement & 0.185 & 26.119 \\
Water & 0.075 & 10.589 \\
Coarse Aggregate & 0.377 & 53.277 \\
Fine Aggregate, Sand & 0.363 & 51.250 \\
TOTAL & 1 & 141.186 \\
\hline
\end{tabular}


Figure 2- IoT ecosystem for connecting piezoceramic sensor to cloud server

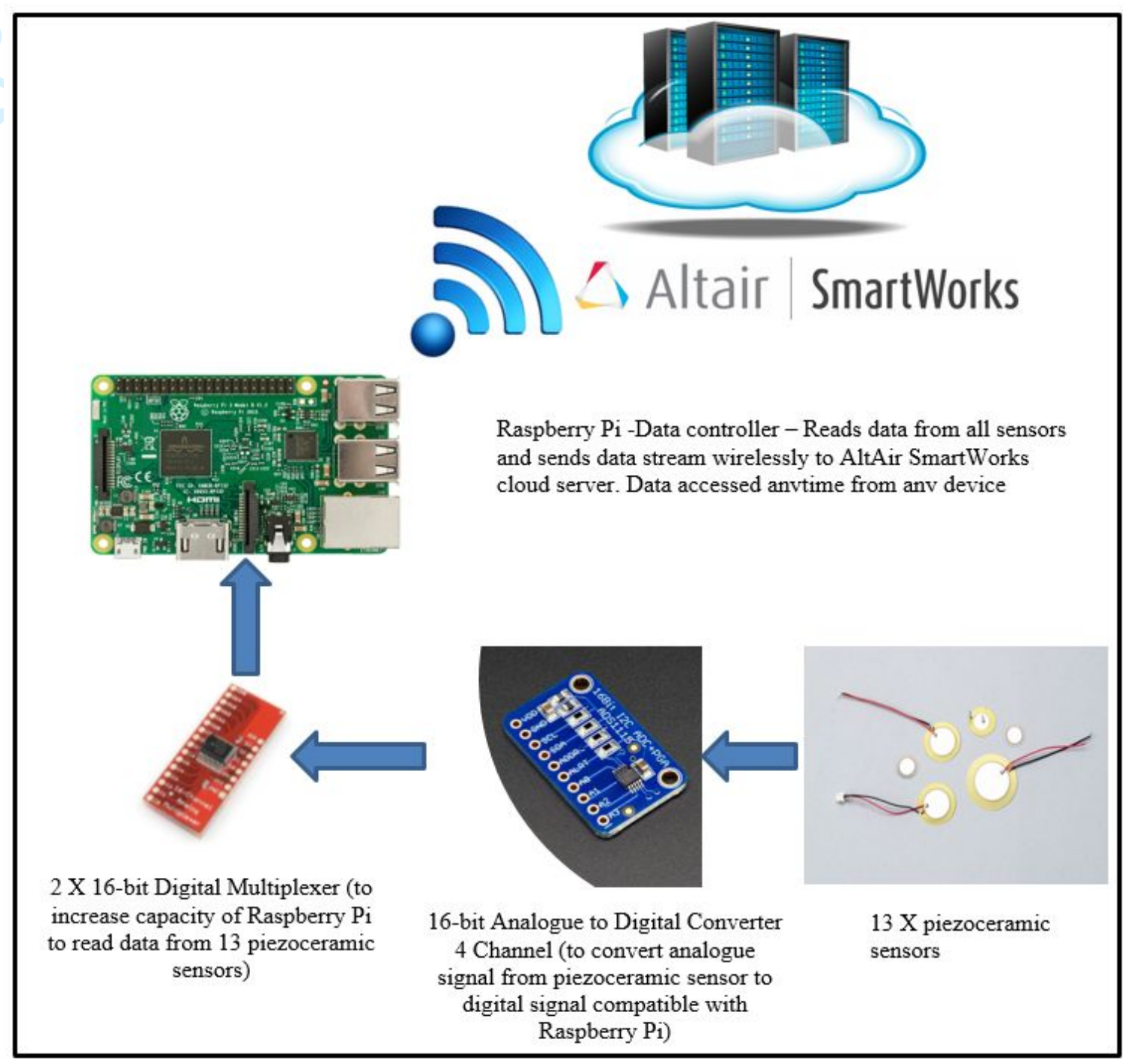


Figure 3 - Screenshot of AltAir SmartWorks datastream program running code and results in numbers (voltage)

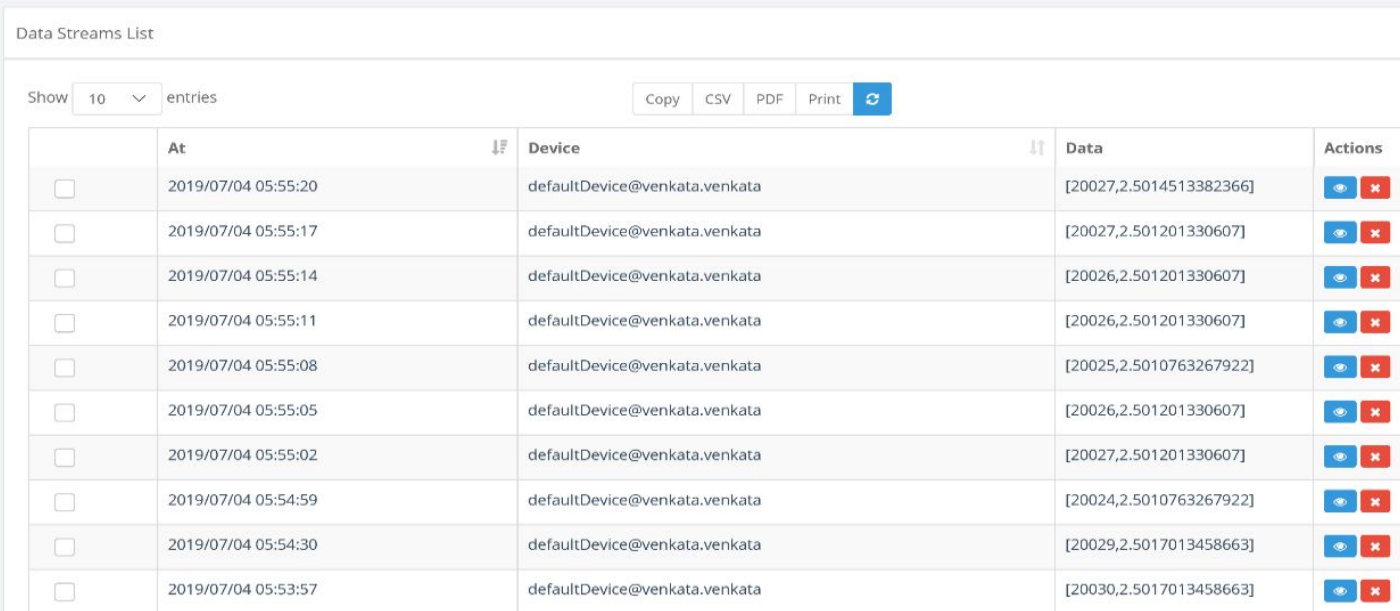


Figure 4 - Experimental Setup with three-point bending machine, piezoceramic sensors attached to Raspberry Pi and connected to monitor to run the code

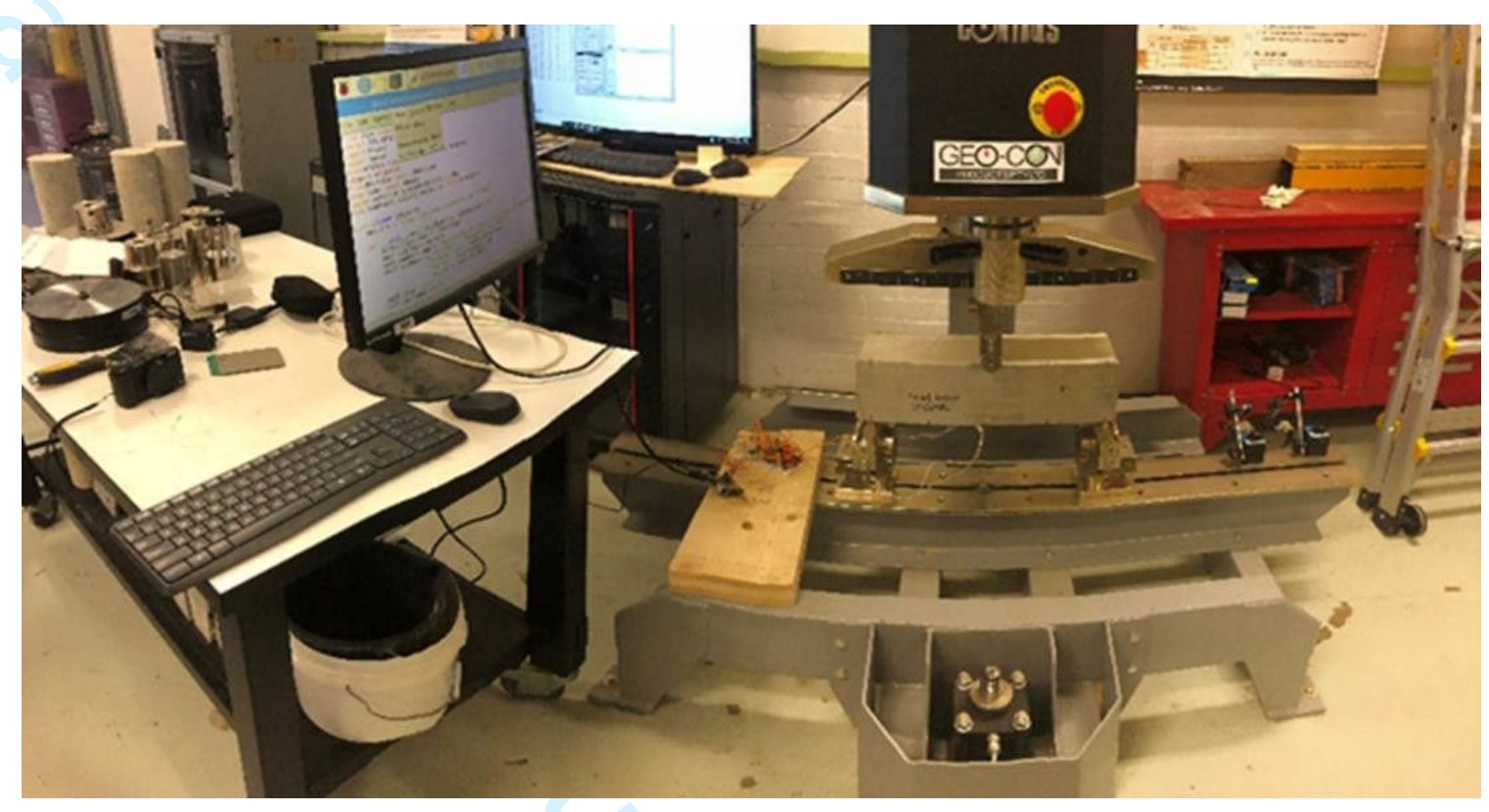


Figure 5 - Layout of sensors on each beam (Not to Scale)

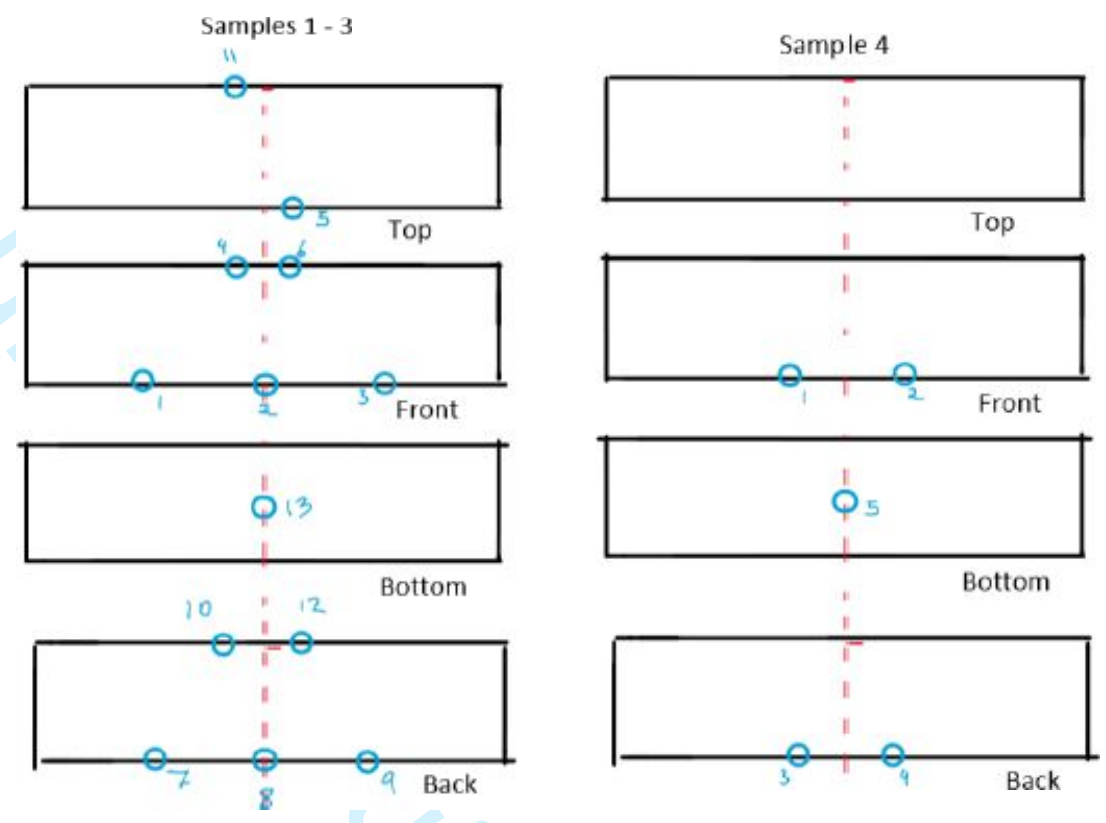


Figure 6- Sensor arrangement for beam 1

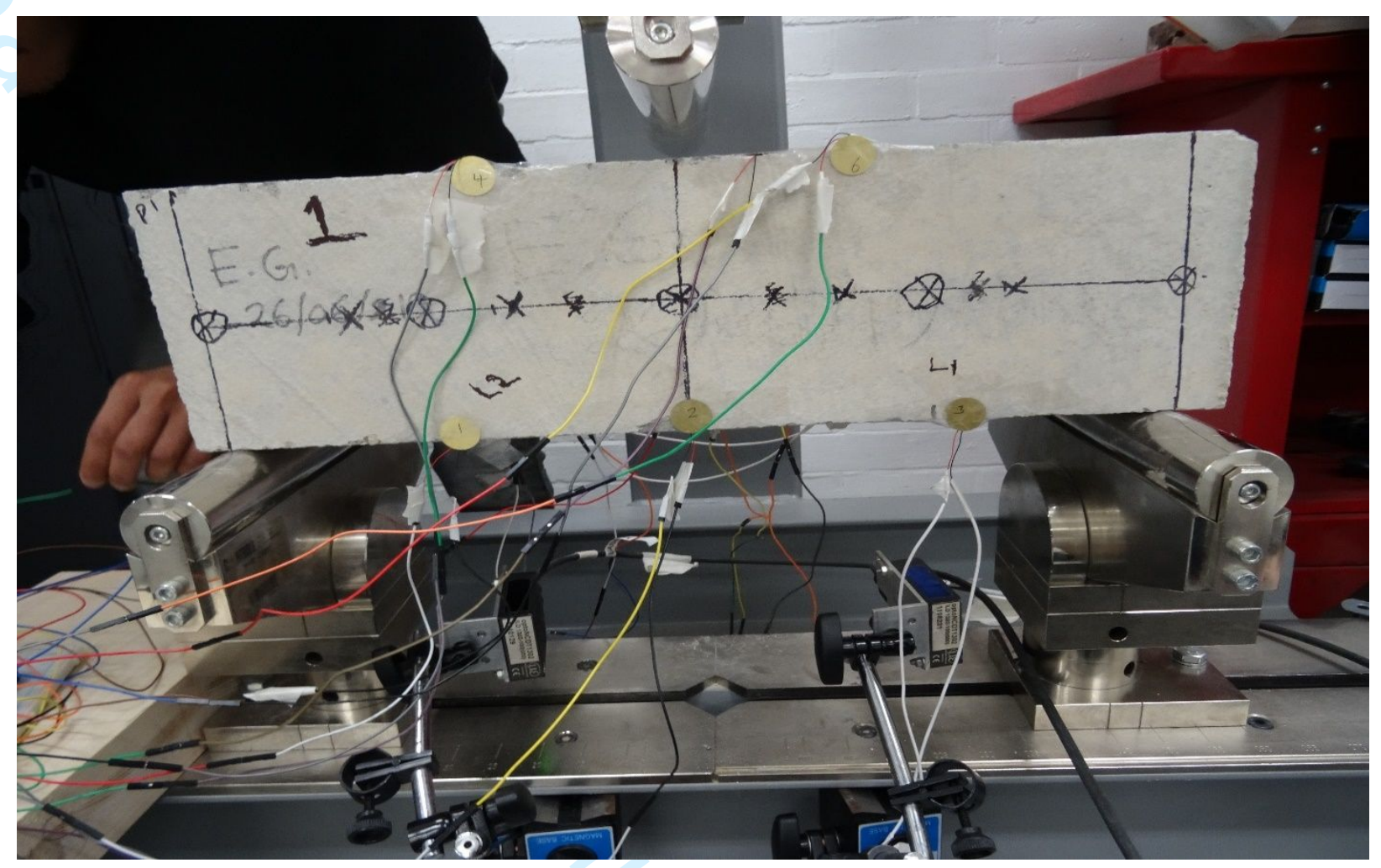


International Journal of Building Pathology and Adaptation

Page 32 of 39

1

2

3

4

Figure 7- Load Displacement curve for beam 1

5

6

Load Displacement Curve for Sample 1

7

8

9

10

11

12

13

14

15

16

17

18

19

20

21

22

23

24

25

26

27

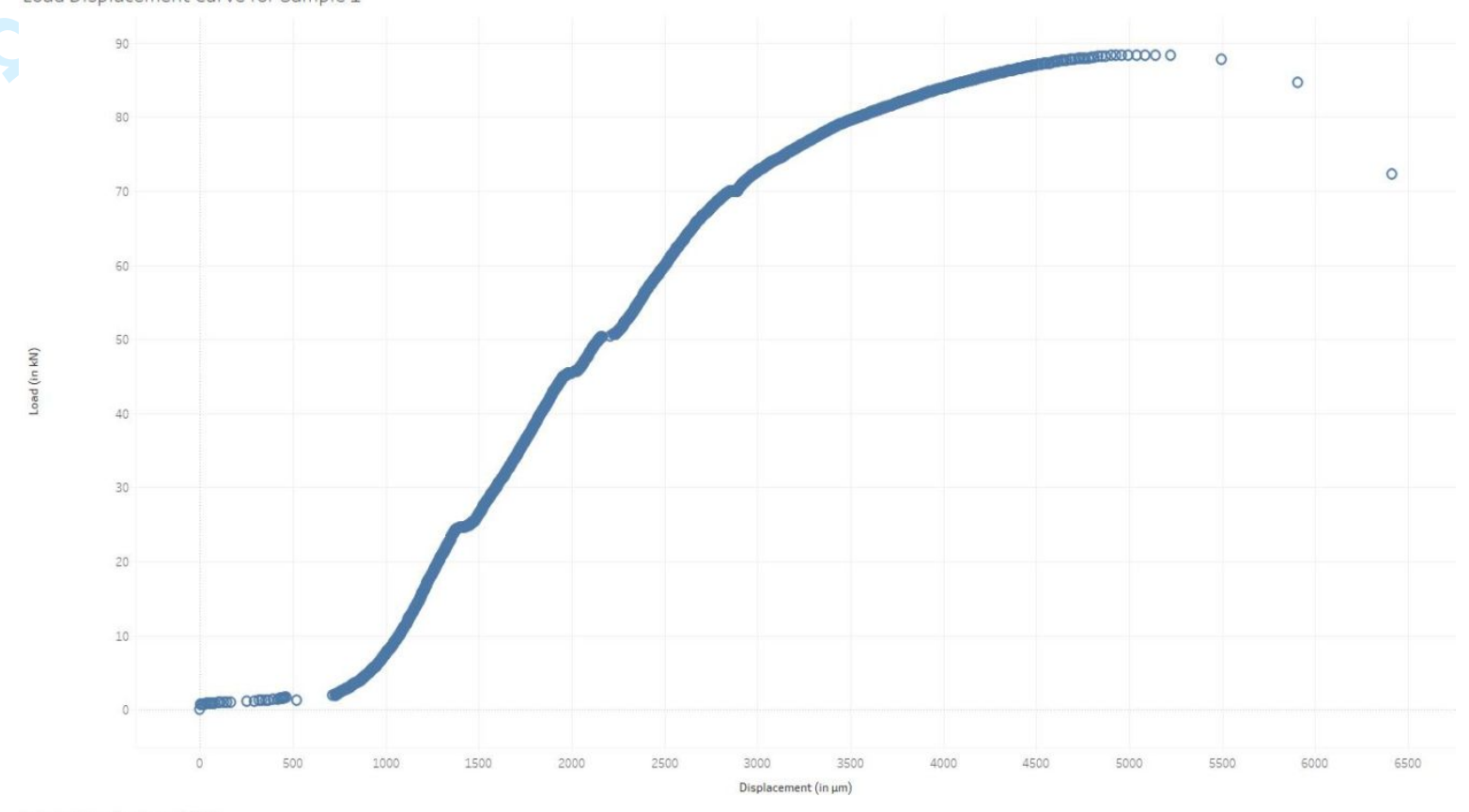

28

29

30

31

32

33

34

35

36

37

38

39

40

41

42

43

44

45

46

47

48

49

50

51

52

53

54

55

56

57

58

59

60

Displacement ch 8 um vs. Load ch $2 \mathrm{kN}$ 
Figure 8 - Test 1 Sample 1 Sensor Readings vs LVDT strain displacement readings on beam 1
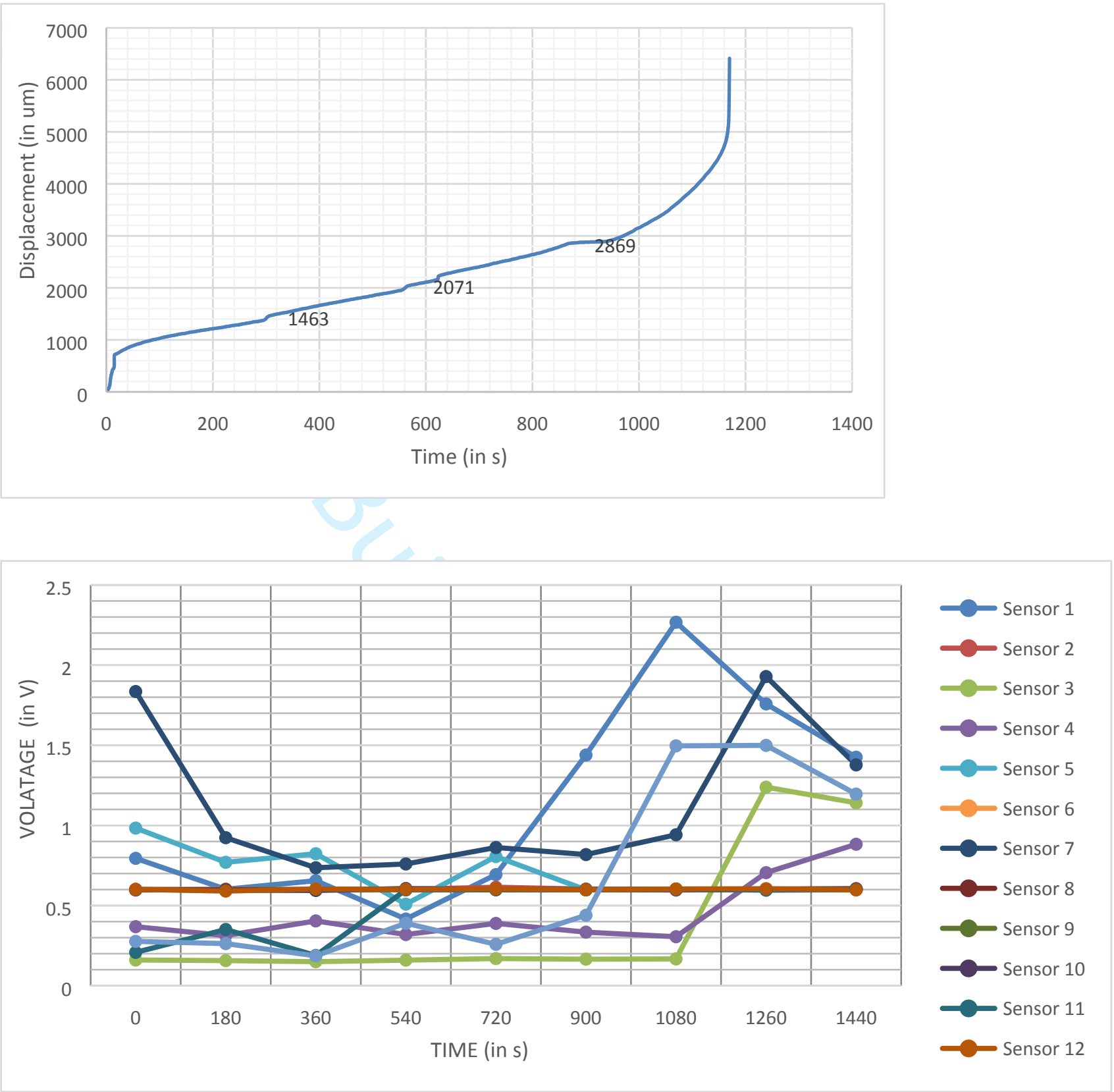
Appendix 1 - Major traditional SHM methods

\begin{tabular}{|c|c|c|c|c|c|}
\hline $\begin{array}{l}\text { Observation } \\
\text { Technique }\end{array}$ & Method and Principle & $\begin{array}{l}\text { Cost of } \\
\text { apparatus (in } \\
\text { AUD) }\end{array}$ & Application & Limitations & Reference \\
\hline Human eye & Principle of photography. & Nil & \multirow{5}{*}{$\begin{array}{l}\text { Rapid detection of superficial flaws like } \\
\text { cracking, seepage, spalling, exposed } \\
\text { reinforcement, staining, moisture ingress, } \\
\text { beam delamination, rencrete } \\
\text { deterioration, and reinforcement } \\
\text { corrosion. }\end{array}$} & \multirow{5}{*}{$\begin{array}{l}\text { Labour intensive, doesn't } \\
\text { offer detailed or } \\
\text { quantitative information } \\
\text { about interior defects. }\end{array}$} & \multirow{5}{*}{$\begin{array}{l}\text { (Davis et al. } \\
\text { 1998), (Park } \\
\text { et al. 2001), } \\
\text { (Gokhan } \\
\text { 2013) }\end{array}$} \\
\hline $\begin{array}{l}\text { Hand-held } \\
\text { magnifier }\end{array}$ & Principle of magnification. & $\$ 36$ & & & \\
\hline $\begin{array}{l}\text { Stereo } \\
\text { microscope }\end{array}$ & $\begin{array}{l}\text { Combination of fixed and } \\
\text { pancreatic magnification. }\end{array}$ & $\$ 2000-4000$ & & & \\
\hline Fibrescope & Total internal reflection. & $\$ 290$ & & & \\
\hline Borescope & $\begin{array}{l}\text { Using lens attached through an } \\
\text { adapter to a CCD camera for } \\
\text { viewing real-time video. }\end{array}$ & $\$ 100-60,000$ & & & \\
\hline $\begin{array}{l}\text { Rebound } \\
\text { hammer/soni } \\
\text { c echo }\end{array}$ & $\begin{array}{l}\text { Hammer impact on surface and } \\
\text { receiver monitors reflected stress } \\
\text { wave. Time-domain analysis is } \\
\text { used to determine travel time. }\end{array}$ & $\$ 1500$ & $\begin{array}{l}\text { Determine the length of deep foundations } \\
\text { (piles and piers), location of cracks or } \\
\text { constrictions (neck-in). }\end{array}$ & $\begin{array}{l}\text { Confuses necking and } \\
\text { bulging. Does not } \\
\text { measure diameter; unable } \\
\text { to detect defects in shafts } \\
>30 \mathrm{~m} \text {. }\end{array}$ & $\begin{array}{l}\text { (Alani, } \\
\text { Aboutalebi } \\
\text { \& Kilic } \\
\text { 2014) }\end{array}$ \\
\hline $\begin{array}{l}\text { Ultrasonic } \\
\text { pulse } \\
\text { velocity } \\
\text { (UPV) test }\end{array}$ & $\begin{array}{l}\text { Measure the travel time of a pulse } \\
\text { of ultrasonic waves over a known } \\
\text { path length. }\end{array}$ & $\$ 2,247$ & $\begin{array}{l}\text { Determine the relative condition of } \\
\text { concrete based on measured pulse } \\
\text { velocity. }\end{array}$ & $\begin{array}{l}\text { Requires two-sided access } \\
\text { to members; does not } \\
\text { provide information on } \\
\text { depth of defect. }\end{array}$ & $\begin{array}{l}\text { (Davis et al. } \\
\text { 1998) }\end{array}$ \\
\hline $\begin{array}{l}\text { Ultrasonic } \\
\text { echo }\end{array}$ & $\begin{array}{l}\text { Emission of a short pulse of } \\
\text { ultrasonic waves and measurement } \\
\text { of the arrival of reflected echo } \\
\text { pulse by adjacent receiver. }\end{array}$ & $\$ 12,334$ & $\begin{array}{l}\text { Locate delaminations and voids in } \\
\text { relatively thin elements. }\end{array}$ & $\begin{array}{l}\text { Primarily a research tool } \\
\text { with limitations in } \\
\text { penetration depth, } \\
\text { resolution, and imaging } \\
\text { capabilities. }\end{array}$ & $\begin{array}{l}\text { (Niederleithi } \\
\text { nger et al. } \\
\text { 2019) }\end{array}$ \\
\hline Impact echo & Receiver. & $\$ 11,560$ & $\begin{array}{l}\text { Locate a variety of defects within concrete } \\
\text { elements such as delaminations, voids, } \\
\text { honeycombing or measure element } \\
\text { thickness. }\end{array}$ & $\begin{array}{l}\text { Current instrumentation } \\
\text { limits members to less } \\
\text { than } 2 \mathrm{~m} \text { thickness. }\end{array}$ & $\begin{array}{l}\text { (Kachanov } \\
\text { et al. 2019) }\end{array}$ \\
\hline $\begin{array}{l}\text { Spectral } \\
\text { analysis of } \\
\text { surface } \\
\text { waves }\end{array}$ & $\begin{array}{l}\text { Impact used to generate a surface } \\
\text { wave, and two receivers monitor } \\
\text { the surface motion with a } \\
\text { subsequent } \quad \text { signal analysis }\end{array}$ & $\$ 10$ per meter & $\begin{array}{l}\text { Determination of stiffness profile of a } \\
\text { pavement system and depth of } \\
\text { deteriorated concrete. }\end{array}$ & $\begin{array}{l}\text { Involves complex signal } \\
\text { processing. }\end{array}$ & $\begin{array}{l}\text { (Rodriguez- } \\
\text { Roblero et } \\
\text { al. 2019) }\end{array}$ \\
\hline
\end{tabular}




\begin{tabular}{|l|l|l|l|l|l|}
\hline $\begin{array}{l}\text { Observation } \\
\text { Technique }\end{array}$ & Method and Principle & $\begin{array}{l}\text { Cost of } \\
\text { apparatus (in } \\
\text { AUD) }\end{array}$ & Application & Limitations \\
\hline & $\begin{array}{l}\text { determination of wave speed } \\
\text { which leads to calculation of the } \\
\text { elastic constant of layers. }\end{array}$ & & & & \\
\hline $\begin{array}{l}\text { Impedance } \\
\text { lagging }\end{array}$ & $\begin{array}{l}\text { Use of complex signal (time and } \\
\text { domain) analysis allowing. }\end{array}$ & $\$ 150-300$ & $\begin{array}{l}\text { Determine the approximate 2D shape of } \\
\text { deep foundation. }\end{array}$ & $\begin{array}{l}\text { High-quality fequirement, full analysis } \\
\text { requires lab environment. }\end{array}$ & $\begin{array}{l}\text { (Paquet } \\
1991)\end{array}$ \\
\hline $\begin{array}{l}\text { Crosshole } \\
\text { sonic lagging }\end{array}$ & $\begin{array}{l}\text { Transducers positioned within } \\
\text { tubes cast into deep foundation or } \\
\text { holes drilled after construction. }\end{array}$ & $\$ 200-400$ & $\begin{array}{l}\text { Determine the location of low-quality } \\
\text { concrete along the length of the shaft and } \\
\text { between transducers. With drilled holes } \\
\text { permits direct determination of shaft } \\
\text { length. }\end{array}$ & $\begin{array}{l}\text { Pre-placed tubes or coring } \\
\text { required, the edge of shaft } \\
\text { defects may not be } \\
\text { detected. }\end{array}$ & $\begin{array}{l}\text { (White, } \\
\text { Nagy \& } \\
\text { Allin 2008) }\end{array}$ \\
\hline $\begin{array}{l}\text { Parallel } \\
\text { seismic }\end{array}$ & $\begin{array}{l}\text { Receiver is placed in hole adjacent } \\
\text { to foundation. Foundation is struck } \\
\text { with a hammer and signal from the } \\
\text { receiver is recorded. }\end{array}$ & $\$ 33,800$ & $\begin{array}{l}\text { Determine the foundation depth and } \\
\text { determine whether it is of uniform quality. }\end{array}$ & $\begin{array}{l}\text { Signal stops at first } \\
\text { significant anomaly. Edge } \\
\text { defects may be bypassed. }\end{array}$ & $\begin{array}{l}\text { (Rashidyan, } \\
\text { Maji \& Ng } \\
2019)\end{array}$ \\
\hline $\begin{array}{l}\text { Chain drag } \\
\text { and hammer } \\
\text { sounding }\end{array}$ & $\begin{array}{l}\text { Involves dragging lengths of chain } \\
\text { across the top of a concrete } \\
\text { surface with a distinctly hollow, } \\
\text { drum-like sound heard when } \\
\text { delaminations are encountered. }\end{array}$ & $\$ 30$ & $\begin{array}{l}\text { Easy and quick superficial investigation of } \\
\text { surface defects. }\end{array}$ & $\begin{array}{l}\text { Labour } \\
\text { efficiency and reliability } \\
\text { dependent on operator } \\
\text { expertise, usually used in } \\
\text { conjunction with other } \\
\text { tests like acoustic } \\
\text { techniques or radar. }\end{array}$ & $\begin{array}{l}\text { (Barnes, } \\
\text { Trottier \& } \\
\text { Forgeron }\end{array}$ \\
\hline
\end{tabular}


Appendix 2 - Review of sensor-based techniques for structural health monitoring of concrete members

\begin{tabular}{|c|c|c|c|c|c|}
\hline $\begin{array}{l}\text { Sensing } \\
\text { Technique }\end{array}$ & Method and Principle & $\begin{array}{l}\text { Cost of } \\
\text { apparatus } \\
\text { (in AUD) }\end{array}$ & Application & Limitations & Reference \\
\hline Strain Gauge & $\begin{array}{l}\text { Can be mechanical, electrical (LVDT), } \\
\text { acoustic or electrical displacement. } \\
\text { Measures the reaction of the structure to } \\
\text { the applied load. }\end{array}$ & $\$ 600$ & $\begin{array}{l}\text { Monitor crack growth, thermal } \\
\text { stress (in conjunction with } \\
\text { temperature sensor), provide real- } \\
\text { time monitoring of strain. }\end{array}$ & $\begin{array}{l}\text { Unsuitable for dynamic tests due to its } \\
\text { slow response time, constant electric } \\
\text { supply necessary and avoidance } \\
\text { magnetic disturbances required, low } \\
\text { fatigue life. }\end{array}$ & $\begin{array}{l}\text { (Kaklauskas et } \\
\text { al. 2019b) }\end{array}$ \\
\hline Piezoceramic ${ }^{*}$ & $\begin{array}{l}\text { Conversion of mechanical vibrations } \\
\text { emitted from even micro cracks to } \\
\text { measurable electrical voltage. }\end{array}$ & $\begin{array}{l}\$ 2.22 \text { per } \\
\text { sensor }+ \\
\$ 50 \\
\text { controller }\end{array}$ & $\begin{array}{l}\text { Ability to measure variations in } \\
\text { parameters such } \\
\text { as acoustic emission, temperature, } \\
\text { strain, force, pressure, or } \\
\text { acceleration. }\end{array}$ & $\begin{array}{l}\text { Fragile, unsuitable for humid } \\
\text { environment, low life-span, bonding } \\
\text { of sensor with concrete member. }\end{array}$ & $\begin{array}{l}\text { (Pan, Wong \& } \\
\text { Su 2019) }\end{array}$ \\
\hline $\begin{array}{l}\text { Shape memory } \\
\text { alloy }\end{array}$ & $\begin{array}{l}\text { Utilize the shape memory effect (SME) to } \\
\text { revert to their original shape upon heating } \\
\text { after being deformed; use magnetic field } \\
\text { sensing technique to monitor the } \\
\text { structural health of concrete members. }\end{array}$ & $\begin{array}{l}\$ 60-70 \text { per } \\
\text { sheet }\end{array}$ & $\begin{array}{l}\text { Used in near surface-mounted } \\
\text { strengthening reinforcement (NSM) } \\
\text { to enhance serviceability and easy } \\
\text { monitoring of prestressed concrete. }\end{array}$ & $\begin{array}{l}\text { External magnetic disturbances from } \\
\text { reinforcement could distort readings. }\end{array}$ & $\begin{array}{l}\text { (Abouali et al. } \\
\text { 2019) }\end{array}$ \\
\hline $\begin{array}{l}\text { Temperature } \\
\text { and humidity }\end{array}$ & $\begin{array}{l}\text { Measurement of temperature and } \\
\text { humidity parameters through negative } \\
\text { temperature coefficient (NTC) } \\
\text { thermistors, resistance temperature } \\
\text { detector (RTD), thermocouples, } \\
\text { infrared sensors, thermometers, change- } \\
\text { of-state sensors, silicon diodes and } \\
\text { semiconductor-based sensors. }\end{array}$ & $\begin{array}{l}\$ 29 \text { per } \\
\text { sensor }+ \\
\$ 50 \\
\text { controller }\end{array}$ & $\begin{array}{l}\text { Optimising concrete curing process, } \\
\text { minimising thermal stress, drying } \\
\text { shrinkage, autogenous and plastic } \\
\text { shrinkage. }\end{array}$ & $\begin{array}{l}\text { Most temperature sensors are unable } \\
\text { to survive in harsh alkaline concrete } \\
\text { environment; problems of signal } \\
\text { transmission stability, antenna design, } \\
\text { electrical power, maintenance, } \\
\text { database size, or the influence of } \\
\text { structural strength. }\end{array}$ & $\begin{array}{l}\text { (Chang \& } \\
\text { Hung 2012) }\end{array}$ \\
\hline Bulk form & $\begin{array}{l}\text { Entire structure made of self-sensing } \\
\text { concrete using carbon fibre or polyvinyl } \\
\text { alcohol fibres or carbon nanotubes. }\end{array}$ & $\begin{array}{l}\$ 16,600 / \mathrm{kg} \\
\text { for } 0.5 \mathrm{wt} \text {. } \\
\% \\
\text { multiwall } \\
\text { carbon } \\
\text { nanotube( } \\
\text { MWNT) }\end{array}$ & $\begin{array}{l}\text { Monitor the extent of fatigue } \\
\text { damage, self-monitoring own strain, } \\
\text { crack detection and propagation } \\
\text { prediction of deflection of bridges. }\end{array}$ & $\begin{array}{l}\text { Expensive filler materials of carbon } \\
\text { nanofiber, polyvinyl alcohol. Need to } \\
\text { monitor loading results in lab } \\
\text { environment. }\end{array}$ & $\begin{array}{l}\text { (Howser, } \\
\text { Dhonde \& Mo } \\
\text { 2011; Zhang et } \\
\text { al. 2004) }\end{array}$ \\
\hline
\end{tabular}




\begin{tabular}{|c|c|c|c|c|c|}
\hline $\begin{array}{l}\text { Sensing } \\
\text { Technique }\end{array}$ & Method and Principle & $\begin{array}{l}\text { Cost of } \\
\text { apparatus } \\
\text { (in AUD) }\end{array}$ & Application & Limitations & Reference \\
\hline Coating form & $\begin{array}{l}\text { One surface of structure/component } \\
\text { covered with a layer of self-sensing } \\
\text { composite. }\end{array}$ & $\begin{array}{l}\$ 8000 / \mathrm{kg} \\
\text { for } \\
0.034 \mathrm{wt} . \% \\
\text { sand-coated } \\
\text { MWNT }\end{array}$ & $\begin{array}{l}\text { Compressive and tensile strain } \\
\text { monitoring of concrete members, } \\
\text { early warning system of fracture, } \\
\text { ultimate load, and rigidity. }\end{array}$ & $\begin{array}{l}\text { Although it could act as a potential } \\
\text { strain sensor but it couldn't act as a } \\
\text { feasible damage sensor due to the low } \\
\text { strains experience by concrete. }\end{array}$ & $\begin{array}{l}\text { (Baeza et al. } \\
\text { 2013) }\end{array}$ \\
\hline $\begin{array}{l}\text { Sandwich } \\
\text { form }\end{array}$ & $\begin{array}{l}\text { Both top and bottom layers of a } \\
\text { structure/component covered with self- } \\
\text { sensing concrete layers. }\end{array}$ & $\begin{array}{l}\$ 10,000 / \mathrm{kg} \\
\text { for } 0.1 \% \\
\text { MWNT }\end{array}$ & $\begin{array}{l}\text { Within elastic stage, sandwich } \\
\text { concrete members capable of stress } \\
\text { and strain monitoring of both } \\
\text { compressive and tensile zones. }\end{array}$ & $\begin{array}{l}\text { Expensive filler materials of carbon } \\
\text { nanofiber, polyvinyl alcohol. Need to } \\
\text { monitor loading results in lab } \\
\text { environment. }\end{array}$ & $\begin{array}{l}\text { (Wu, Dai \& } \\
\text { Wang 2007) }\end{array}$ \\
\hline $\begin{array}{l}\text { Embedded } \\
\text { form }\end{array}$ & $\begin{array}{l}\text { Self-sensing concrete is prefabricated into } \\
\text { standard small-size sensors which is then } \\
\text { embedded into the structure. }\end{array}$ & $\begin{array}{l}\$ 8210 / \mathrm{kg} \\
\text { for } 0.05 \% \\
\text { MWNT }\end{array}$ & $\begin{array}{l}\text { Stress and strain of both } \\
\text { compressive and tensile zones } \\
\text { within elastic range, loading, } \\
\text { deflection, crack and damage extent } \\
\text { of concrete members. }\end{array}$ & $\begin{array}{l}\text { Difficult to prefabricate embedded } \\
\text { concrete sensors, laboratory } \\
\text { environment required for monitoring } \\
\text { of loading characteristics. }\end{array}$ & $\begin{array}{l}\text { (Fan et al. } \\
2011 \text { ) }\end{array}$ \\
\hline Bonded form & $\begin{array}{l}\text { Small sensors made of self-sensing } \\
\text { concrete attached to concrete members } \\
\text { using adhesive materials. }\end{array}$ & $\begin{array}{l}\$ 8000 / \mathrm{kg} \\
\text { for } \\
0.034 \mathrm{wt} . \% \\
\text { sand-coated } \\
\text { MWNT }\end{array}$ & $\begin{array}{l}\text { Composites could act as strain } \\
\text { sensors even for severely damaged } \\
\text { structures near collapse. }\end{array}$ & $\begin{array}{l}\text { Adhesive material not waterproof, } \\
\text { long-lasting feature of bonded. }\end{array}$ & $\begin{array}{l}\text { (Camacho- } \\
\text { Ballesta et al. } \\
\text { 2019) }\end{array}$ \\
\hline $\begin{array}{l}\text { Fibre Bragg } \\
\text { Grating (FBG) }\end{array}$ & $\begin{array}{l}\text { Periodic variation of the refractive index } \\
\text { along the fiber length formed by exposure } \\
\text { of the core to an intense optical } \\
\text { interference pattern. }\end{array}$ & $\begin{array}{l}\$ 15-50 \text { per } \\
\mathrm{m}^{2}\end{array}$ & $\begin{array}{l}\text { Measurement stability and } \\
\text { leading/interconnecting } \\
\text { insensitivity; inherent immunity } \\
\text { from signal intensity fluctuations. }\end{array}$ & $\begin{array}{l}\text { Expensive, fragile, specialist expertise } \\
\text { in construction and deployment of } \\
\text { fibres and need for several repeaters } \\
\text { to boost the signal. }\end{array}$ & $\begin{array}{l}\text { (Moyo et al. } \\
2005 \text { ) }\end{array}$ \\
\hline Hybrid sensors & $\begin{array}{l}\text { Combination of two or more fibre optic } \\
\text { sensors (FOS) to monitor multiple } \\
\text { parameters simultaneously (e.g. strain and } \\
\text { temperature). }\end{array}$ & $\$ 1500-3000$ & $\begin{array}{l}\text { Hybrid optical fiber sensors having } \\
\text { capability of discriminating between } \\
\text { strain, temperature and thermal } \\
\text { strain provides one-stop solution for } \\
\text { SHM applications. }\end{array}$ & $\begin{array}{l}\text { Complicated interrogation techniques } \\
\text { are required for analysis of multiple } \\
\text { parameters. }\end{array}$ & $\begin{array}{l}\text { (Patrick et al. } \\
\text { 1996), } \\
\text { (Kaklauskas et } \\
\text { al. 2019a) }\end{array}$ \\
\hline $\begin{array}{l}\text { Direct } \\
\text { transmission } \\
\text { radiometry }\end{array}$ & $\begin{array}{l}\text { Measure the intensity of high-energy } \\
\text { electromagnetic radiation after passing } \\
\text { through concrete. }\end{array}$ & $\$ 600-1200$ & $\begin{array}{l}\text { Easy and rapid determination of in- } \\
\text { place density with minimal operator } \\
\text { skill and portable equipment. }\end{array}$ & $\begin{array}{l}\text { Available equipment limited to path } \\
\text { lengths below } 300 \mathrm{~mm} \text {. Requires } \\
\text { access to the inside member of } \\
\text { opposite faces. }\end{array}$ & $\begin{array}{l}\text { (Bień, } \\
\text { Kamiński \& } \\
\text { Kużawa 2019) }\end{array}$ \\
\hline Backscatter & Measure the intensity of high-energy & $\$ 600-1200$ & Suitable for fresh or hardened & Precision of density measurements & (Venkatraman \\
\hline
\end{tabular}




\begin{tabular}{|c|c|c|c|c|c|}
\hline $\begin{array}{l}\text { Sensing } \\
\text { Technique }\end{array}$ & Method and Principle & $\begin{array}{l}\text { Cost of } \\
\text { apparatus } \\
\text { (in AUD) } \\
\end{array}$ & Application & Limitations & Reference \\
\hline radiometry & $\begin{array}{l}\text { electromagnetic radiation that is } \\
\text { backscattered (reflected) by near-surface } \\
\text { region of a concrete member. }\end{array}$ & & $\begin{array}{l}\text { concrete. Portable equipment } \\
\text { facilitates rapid testing. }\end{array}$ & $\begin{array}{l}\text { lower than direct transmission. } \\
\text { Material chemical composition affects } \\
\text { measurements. }\end{array}$ & \& Raj 2019) \\
\hline Radiography & $\begin{array}{l}\text { Recording of the intensity of high-energy } \\
\text { electromagnetic radiation on a } \\
\text { photographic film. }\end{array}$ & $\$ 1500-4000$ & $\begin{array}{l}\text { Provides an internal structural view } \\
\text { of studied object. }\end{array}$ & $\begin{array}{l}\text { Difficult to identify cracks } \\
\text { perpendicular to the radiation beam. } \\
\text { Gamma-ray penetration limited to } \\
\text { 500mm of concrete. Bulky and } \\
\text { expensive X-ray equipment. }\end{array}$ & $\begin{array}{l}\text { (Anton, } \\
\text { Komárková \& } \\
\text { Heřmánková } \\
\text { 2019) }\end{array}$ \\
\hline Covermeter & $\begin{array}{l}\text { Low frequency alternating magnetic field } \\
\text { applied on the surface of structure and } \\
\text { depth of reinforcement cover is gauged } \\
\text { from alteration of the magnetic field. }\end{array}$ & $\$ 800-1500$ & $\begin{array}{l}\text { Locate embedded steel } \\
\text { reinforcement, measure the depth of } \\
\text { cover, estimate diameter of } \\
\text { reinforcement. }\end{array}$ & $\begin{array}{l}\text { Accuracy of estimated cover depth } \\
\text { affected by bar size and spacing, } \\
\text { unable to detect presence of second } \\
\text { layer of reinforcement, only } \\
\text { ferromagnetic objects can be detected. }\end{array}$ & $\begin{array}{l}\text { (Cikrle et al. } \\
\text { 2019) }\end{array}$ \\
\hline $\begin{array}{l}\text { Half-cell } \\
\text { potential }\end{array}$ & $\begin{array}{l}\text { Measure voltage between steel } \\
\text { reinforcement and standard reference } \\
\text { electrode. }\end{array}$ & $\$ 3000-4000$ & Detect corrosion of reinforcement. & $\begin{array}{l}\text { Embedded reinforcement to be } \\
\text { electrically connected, no indication } \\
\text { of corrosion rate, concrete should be } \\
\text { moist. }\end{array}$ & $\begin{array}{l}\text { (Garcia \& } \\
\text { Deby 2019) }\end{array}$ \\
\hline $\begin{array}{l}\text { Polarization } \\
\text { methods }\end{array}$ & $\begin{array}{l}\text { Measure current required to change the } \\
\text { voltage between reinforcement and } \\
\text { standard reference electrode; measured } \\
\text { current and voltage provide resistance } \\
\text { value which is related to corrosion. }\end{array}$ & $\$ 70-140$ & $\begin{array}{l}\text { Determination of instantaneous } \\
\text { corrosion rate of reinforcement } \\
\text { located below test point. }\end{array}$ & $\begin{array}{l}\text { No standards for interpreting test } \\
\text { results, concrete surface to be smooth } \\
\text { and uncracked and free of } \\
\text { impermeable coating. }\end{array}$ & $\begin{array}{l}\text { (Khajehnouri } \\
\text { et al. 2019) }\end{array}$ \\
\hline $\begin{array}{l}\text { Penetrability } \\
\text { methods }\end{array}$ & $\begin{array}{l}\text { Measure fluid flow rate into concrete } \\
\text { under prescribed condition which } \\
\text { depends on the penetrability } \\
\text { characteristics of concrete. }\end{array}$ & $\begin{array}{l}\$ 2000- \\
10,000\end{array}$ & $\begin{array}{l}\text { Compare alternative concrete } \\
\text { mixtures, assess adequacy of curing } \\
\text { process. Includes ISAT, Figg Water } \\
\text { absorption, covercrete absorption } \\
\text { test, CLAM water permeability, } \\
\text { Steinert Method, Fig Air } \\
\text { permeability, Schonlin Test and } \\
\text { Surface Airflow test. }\end{array}$ & $\begin{array}{l}\text { Does not provide coefficient of } \\
\text { permeability, affected by surface } \\
\text { coatings, concrete surface is damaged, } \\
\text { long test time. }\end{array}$ & $\begin{array}{l}\text { (Yang et al. } \\
\text { 2019) }\end{array}$ \\
\hline $\begin{array}{l}\text { Infrared } \\
\text { thermography }\end{array}$ & $\begin{array}{l}\text { Infrared radiations highlight defects in } \\
\text { concrete through noticeable temperature } \\
\text { difference. }\end{array}$ & $\$ 230-300$ & $\begin{array}{l}\text { Locate delaminations in pavements } \\
\text { and bridge decks and detecting } \\
\text { moist insulation in buildings. }\end{array}$ & $\begin{array}{l}\text { Expensive, requires proper } \\
\text { environmental conditions, depth and } \\
\text { thickness of sub-surface defect cannot }\end{array}$ & $\begin{array}{l}\text { (Rocha, } \\
\text { Póvoas \& } \\
\text { Santos 2019) } \\
\end{array}$ \\
\hline
\end{tabular}




\begin{tabular}{|c|c|c|c|c|c|}
\hline $\begin{array}{l}\text { Sensing } \\
\text { Technique }\end{array}$ & Method and Principle & $\begin{array}{l}\text { Cost of } \\
\text { apparatus } \\
\text { (in AUD) }\end{array}$ & Application & Limitations & Reference \\
\hline & 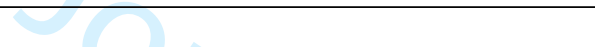 & & & be measured. & \\
\hline Radar & $\begin{array}{l}\text { Electromagnetic waves transmitted and } \\
\text { the reflection time provides a measure of } \\
\text { dielectric properties of the material. }\end{array}$ & $\$ 1500-3000$ & $\begin{array}{l}\text { Locate metal embedments, voids } \\
\text { beneath pavements, regions of high } \\
\text { moisture content and determination } \\
\text { of member thickness. }\end{array}$ & $\begin{array}{l}\text { Cracks And delaminations not easy to } \\
\text { detect unless moisture also present, } \\
\text { limited penetration depth, large data } \\
\text { obtained needs to be properly } \\
\text { processed by experience operator. }\end{array}$ & $\begin{array}{l}\text { (Mehdinia et } \\
\text { al. 2019) }\end{array}$ \\
\hline pH sensor & $\begin{array}{l}\text { Measurement of hydrogen-ion content of } \\
\text { concrete using reference electrodes, } \\
\text { embedding potentiometric } \mathrm{pH} \text { electrodes } \\
\text { or FOS (fire optic) pH sensors. }\end{array}$ & $\$ 100-200$ & $\begin{array}{l}\text { Corrosion monitoring of concrete } \\
\text { sewers, tidal or splash zones in } \\
\text { maritime structures. }\end{array}$ & $\begin{array}{l}\text { Brittleness, chemical instability of } \\
\text { chromophore at high or low pH } \\
\text { values, indicator leaching and } \\
\text { subsequent drifting of signal, } \\
\text { unreliable and long response time. }\end{array}$ & $\begin{array}{l}\text { (Chang \& } \\
\text { Hung 2012) }\end{array}$ \\
\hline $\begin{array}{l}\text { Corrosion } \\
\text { sensor }\end{array}$ & $\begin{array}{l}\text { Measurement of diffusion of } \mathrm{Cl} \text { - ions } \\
\text { alongwith } \mathrm{pH} \text { level using electrodes. }\end{array}$ & $\$ 1400-1800$ & $\begin{array}{l}\text { Monitoring reinforcement corrosion, } \\
\text { external chemical attack on } \\
\text { underwater marine concrete } \\
\text { structures carbonation and chlorine } \\
\text { penetration type corrosion. }\end{array}$ & $\begin{array}{l}\text { Low sensitivity, unreliability, } \\
\text { elongated response time, } \\
\text { incompatibility in hostile } \\
\text { environments, contamination of } \\
\text { electrodes, requirement for periodic } \\
\text { maintenance, short service life and, } \\
\text { focus only on the local corrosion } \\
\text { rather than the spatial scale corrosion } \\
\text { of concrete members. }\end{array}$ & $\begin{array}{l}\text { (Karthick et al. } \\
\text { 2019) }\end{array}$ \\
\hline
\end{tabular}

